Renan Macedo da Rocha

\title{
POSSIBILIDADES JURÍDICAS DE LIMITAÇÃO À DISPENSA COLETIVA: O CASO EMBRAER
}


Universidade de Brasília - UnB

Faculdade de Direito - FD

\title{
POSSIBILIDADES JURÍDICAS DE LIMITAÇÃO À DISPENSA COLETIVA: O CASO EMBRAER
}

\author{
Monografia apresentada à Faculdade de Direito da \\ Universidade de Brasília, como requisito parcial à \\ obtenção do grau de Bacharel em Direito. \\ Orientador: Ricardo Lourenço Filho \\ Aluno: Renan Macedo da Rocha
}

Brasília 
Dedico este trabalho aos meus pais e a toda minha família, que se fazem sempre presentes, mesmo tão longe. Aos meus avós, que aprenderam a usar a internet apenas para falar comigo.

Aos meus amigos, sem os quais eu não teria chegado até aqui.

Ao Ricardo, cuja ajuda foi fundamental para o sucesso desse estudo.

E a Érika, por aturar minha rabugice. 


\section{RESUMO}

O presente estudo parte do caso Embraer, referente às dispensas promovidas pela empresa no início de 2009, para elaborar uma analise da questão da dispensa coletiva de trabalhadores na realidade jurídica nacional. Para isso, realiza-se primeiramente um relato dos fatos e do desenrolar judicial do caso, observando as decisões do TRT da $15^{\text {a }}$ Região e do TST e destacando as principais questões jurídicas suscitadas no debate. A fim de elucidar qual o real poder conferido pelo ordenamento jurídico ao empregador, o trabalho elabora um estudo acerca da figura do FGTS e do chamado poder diretivo. Em seguida, atenta-se para a dispensa coletiva em si, evidenciando a omissão legislativa quanto ao tema no país, em contraste com a vasta regulação conferida por diplomas internacionais. Analisa-se também a definição e os efeitos característicos dessa prática, destacando a posição de alguns autores sobre a necessidade de regulamentação específica sobre a questão. No último capítulo, adentrando o debate central do estudo, o presente trabalho realiza uma crítica à postura dos tribunais quanto ao caso, a partir da teoria de Ronald Dworkin. Por fim, o estudo defende que com o fortalecimento e efetiva atuação dos sindicatos na proteção do trabalhador e a adoção de uma nova postura judicial mais adequada ao paradigma do Estado Democrático de Direito, a melhor interpretação construtiva da prática jurídica da comunidade, mesmo na ausência de dispositivo legal, indica a existência de limites jurídicos à dispensa coletiva.

Palavras-chave: Embraer. Dispensa coletiva. Direitos fundamentais. Direito Sociais. Princípios constitucionais. Ronald Dworkin. Proteção ao trabalhador. Sindicato. 


\section{SUMÁRIO}

INTRODUÇÃ

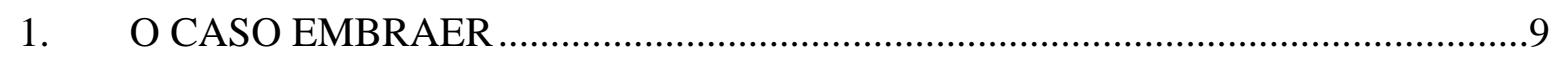

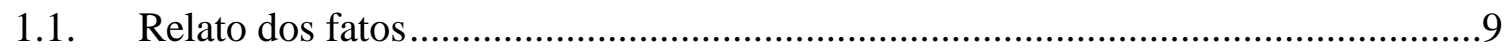

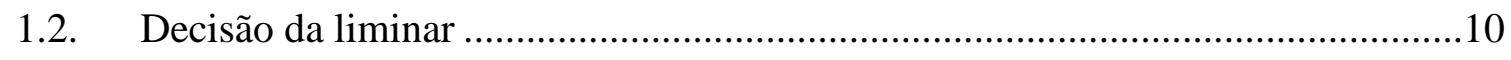

1.3. Julgamento do dissídio coletivo pelo TRT da $15^{\circ}$ Região ..................................13

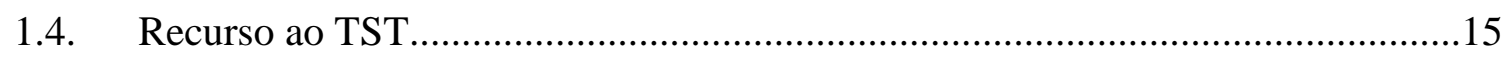

2. O PODER DO EMPREGADOR NA CONSTITUIÇÃO FEDERAL DE $1988 \ldots . . . . . .18$

2.1. O FGTS e a liberalização do mercado de trabalho ...........................................18

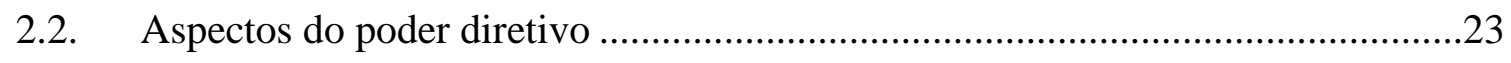

2.2.1. Poder diretivo e atuação sindical .............................................................28

3. A DISPENSA COLETIVA DE TRABALHADORES ...................................................

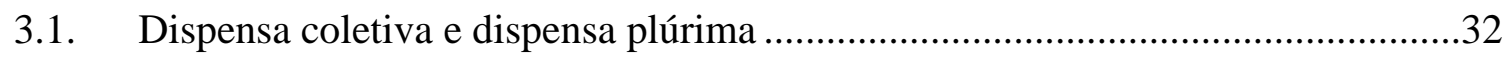

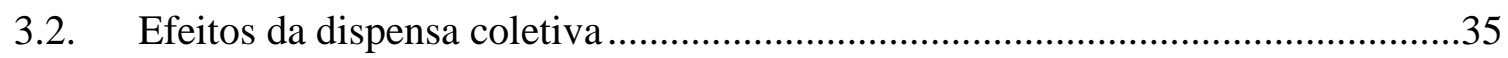

3.3. Necessidade de regulamentação ……............................................................

3.4. A dispensa coletiva no direito internacional: a Convenção n. 158 da OIT............41

4. CAMINHOS PARA A CONSTRUÇÃO DE LIMITES À DISPENSA

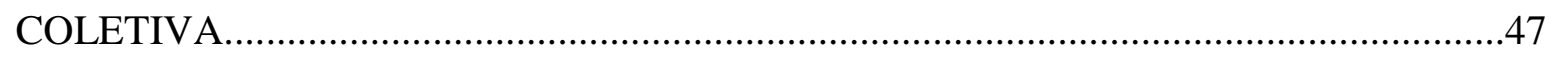

4.1. A postura do juiz dentro do paradigma do Estado Democrático de Direito .........48

4.1.1. Uma leitura principiológica: o Direito como integridade …........................50

4.2.. A eficácia dos princípios fundamentais de proteção ao trabalhador ......................55

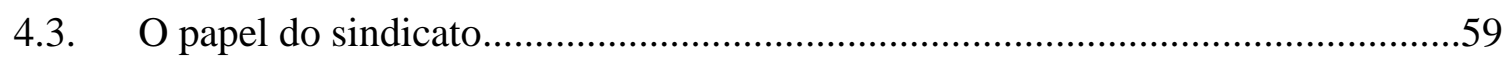

4.3.1. Cenário atual: crise ou decadência? ........................................................63

4.3.2. Novos caminhos para o sindicalismo no Brasil ..........................................67 
CONCLUSÃO .

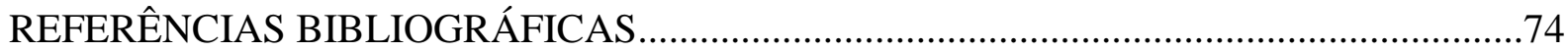




\section{INTRODUÇÃO}

A discussão a ser desenvolvida na presente monografia é a da possibilidade de se construir limites jurídicos para a prática da dispensa coletiva, tendo-se como foco o caso específico da Empresa Brasileira de Aeronáutica - Embraer, que realizou em fevereiro desse ano, motivada pelo quadro de crise econômica mundial, a dispensa de mais de quatro mil de seus empregados.

O Tribunal Regional do Trabalho da $15^{\mathrm{a}}$ Região, em sua decisão sobre o dissídio coletivo, manteve as dispensas realizadas pela empresa, afirmando, contudo, que estas seriam abusivas, uma vez que não houve tentativa de prévia negociação coletiva com o sindicato.

No entendimento do Tribunal Superior do Trabalho, em sua manifestação inicial, a prática da dispensa coletiva pela empresa, com o agravante da crise, não ofendia os princípios constitucionais de proteção e valorização do trabalho, e tampouco o princípio da dignidade humana, considerando assim legítima a medida e mantendo as dispensas efetuadas.

Como não há previsão específica da figura da dispensa coletiva no ordenamento jurídico brasileiro, diferentemente da realidade internacional, torna-se necessária a análise doutrinária do tema, buscando elucidar as questões essenciais envolvidas no problema.

De forma breve, analisa-se primeiramente o modelo do Fundo de Garantia por Tempo de Serviço, universalizado pela Constituição Federal de 1988, e que provocou intensas transformações no âmbito das relações de trabalho, especialmente quanto à possibilidade de rompimento unilateral do contrato pelo empregador. 
Atenta-se também para a análise do poder diretivo do empregador, conforme exposto no art. $2^{\circ}$, caput, da CLT, traçando um esforço no sentido de esclarecer a real concepção desse poder, num sentido mais dinâmico e democrático, afastando a idéia ultrapassada de um poder potestativo.

Tratando da dispensa coletiva em si, o estudo busca sua definição e diferenciação da dispensa individual, e principalmente da chamada dispensa plúrima, em especial diante de seus graves efeitos sociais, expondo assim a visão de alguns autores que defendem a necessidade de uma regulamentação específica sobre o tema.

Adotando como referencial teórico o pensamento de Ronald Dworkin, do direito como integridade, realiza-se uma crítica ao posicionamento dos tribunais diante do caso, defendendo a idéia de uma nova e mais adequada postura frente ao paradigma do Estado Democrático de Direito, positivado pela Constituição de 1988, onde o aplicador do direito deve sempre, considerando o ordenamento jurídico em sua integridade, se empenhar em buscar a única e correta decisão para cada situação concreta.

Por fim, observa-se o importante papel que pode ser desempenhado pelo sindicato, seja através de uma atuação política ou agindo de forma mais específica por meio da negociação coletiva, no sentido de criar e dar efetividade a direitos e garantias do trabalhador. Porém, a essa efetiva atuação sindical, põe-se como obstáculo não apenas a resistência no reconhecimento de sua real importância no âmbito coletivo, mas também o atual quadro de crise ou decadência pela qual atravessa o sindicalismo brasileiro. 


\section{O CASO EMBRAER}

\subsection{Relato dos fatos}

Em 19 de fevereiro do presente ano, a Embraer, terceira maior empresa de seu setor no mundo, anunciou a dispensa de $20 \%$ do seu quadro de empregados, o que representaria um total de 4,27 mil vagas fechadas, como uma medida de enfretamento à crise financeira mundial. Segundo a empresa, a medida se justificaria uma vez que o setor aéreo foi um dos principais afetados, e que ainda que o mercado brasileiro se mostrasse com maior força diante da crise, mais de $90 \%$ do faturamento da empresa era proveniente do mercado externo.

Sem dúvidas, a indústria de aviação civil foi um dos setores mais afetados pela crise mundial, tanto que empresas estrangeiras como a Bombardier e a Boeing igualmente realizaram a dispensa coletiva de mais de quatro mil de seus empregados sob pretexto da crise. Embora se situe no Brasil, a Embraer também sentiu o forte impacto econômico no setor, igualmente às demais empresas internacionais.

No dia 25 do mesmo mês, diante da realização das dispensas pela Embraer, o Sindicato dos Metalúrgicos de São José dos Campos e Região, juntamente com o Sindicato dos Metalúrgicos de Botucatu e a Federação dos Metalúrgicos de São Paulo - sindicatos aos quais os empregados dispensados eram associados - ingressaram com reclamação trabalhista perante o Tribunal Regional do Trabalho da $15^{\text {a }}$ Região, objetivando a anulação das dispensas e a readmissão dos empregados dispensados ao quadro da empresa, além de requererem, em pedido liminar, a suspensão das dispensas até negociação futura ou julgamento. 


\subsection{Decisão da liminar}

O presidente do TRT da $15^{\text {a }}$ Região, Luís Carlos Cândido Martins Sotero da Silva, decidiu por conceder a liminar pleiteada pelos sindicatos e promover a suspensão das dispensas realizadas sob o pretexto da crise econômica até o dia 05 de março do mesmo ano, ocasião em que seria realizada reunião de conciliação entre empregados e empresa.

Ao acionar a Justiça do Trabalho, os suscitantes (empregados) alegaram que o ato praticado pela suscitada (Embraer) "viola direito à informação, pois o empregador deveria ter realizado negociação coletiva prévia com o sindicato de classe ${ }^{1,}$, comunicando a intenção de se proceder às dispensas, possibilitando assim o debate acerca da utilização de medidas alternativas, tais como: redução dos níveis de produção, concessão de férias coletivas, adoção de licença remunerada e redução da jornada de trabalho.

Sustentaram os sindicalistas, em sua reclamação, a inexistência de fundamentos econômicos fortes que motivassem as dispensas e a ocorrência de violação ao princípio da interveniência sindical na negociação coletiva, além de outros princípios constitucionais, expostos nos art. 1, incisos III e IV, art. 5, inciso XIV, art. 7, inciso XXVI, art 8, inciso III e VI. Afirmaram também que a conduta da empresa violava igualmente os ditames da Convenção n. 98 e das Recomendações 94 e 163, todas da Organização Internacional do Trabalho, e os artigos 187 e 422 do Código Civil brasileiro.

Em sua análise, o Presidente do TRT da $15^{\text {a }}$ Região decidiu por conceder a liminar diante do fundamento de que o poder de dispensa do empregador não é absoluto, encontrando limitações nos direitos fundamentais decorrentes do princípio da dignidade da

\footnotetext{
${ }^{1}$ TRIBUNAL REGIONAL DO TRABALHO DA $15^{\text {a }}$ REGIÃO. Seção de Dissídios Coletivos. Processo 003092009-000-15-00-4. Decisão do Desembargador Presidente do TRT da 15a Região e da Seção de Dissídios Coletivos 1, Luís Carlos Cândido Martins Sotero da Silva, em 26 de fevereiro de 2009, Campinas, SP.
} 
pessoa humana. Dessa forma, a fim de se garantir a observância desses direitos, o Presidente destacou a impossibilidade de realização de dispensa coletiva sem prévia negociação sindical, suspendendo as dispensas ocorridas sem justa causa, sob o pretexto de dificuldades financeiras vivenciadas pela empresa, decorrentes da crise econômica global, até a data da audiência de conciliação.

Como expôs em sua fundamentação, o Desembargador Presidente Luís Carlos Cândido afirmou que o princípio da dignidade da pessoa humana funciona como limitador do poder diretivo do empregador, uma vez que:

[...] o conceito de dignidade da pessoa humana obriga a uma densificação valorativa que tenha em conta o seu amplo sentido normativo-constitucional e não uma qualquer idéia apriorística do homem, não podendo reduzir-se o sentido da dignidade humana à defesa dos direitos pessoais tradicionais, esquecendo-a nos casos de direitos sociais ${ }^{2}$.

Partindo, assim, da concepção de dignidade humana como o valor superior que deverá presidir as relações humanas, entre as quais as relações jurídico-trabalhistas, o Presidente do TRT de Campinas reconheceu a relevância e a efetividade dos princípios constitucionais da ordem econômica e da livre concorrência, destacando, porém, que a aplicação de tais princípios deve sempre se fundar na valorização do trabalho humano. Dessa forma, expondo que a lei - acusada, tantas vezes, de superprotetora - dá ao trabalhador muito menos do que promete, e de que a proteção ao emprego compreende também uma proteção ao sindicato e às condições de trabalho, o Desembargador Presidente fundamentou sua decisão ${ }^{3}$.

\footnotetext{
2 TRIBUNAL REGIONAL DO TRABALHO DA $15^{\text {a }}$ REGIÃO. Seção de Dissídios Coletivos. Processo 003092009-000-15-00-4. Decisão do Desembargador Presidente do TRT da 15ª Região e da Seção de Dissídios Coletivos 1, Luís Carlos Cândido Martins Sotero da Silva, em 26 de fevereiro de 2009, Campinas, SP.

${ }^{3}$ Observa-se também que, nos fundamentos de sua decisão, o presidente do TRT menciona o conceito de responsabilidade social da empresa, como um orientador da atuação empresarial, principalmente diante de casos de dispensa coletiva. Porém, não faz maiores menções à questão, carecendo de uma melhor e mais detalhada explicação, no sentido de se definir adequadamente no que consiste tal conceito e de que forma se aplica ao caso discutido. Visto que tal questão não apresentou grande relevância dentro do debate jurídico do
} 
O efeito suspensivo da liminar, válido inicialmente até a data da reunião de conciliação entre sindicalistas e empresa, marcada para o dia 5 de março de 2009, foi mantido até o dia 13 do mesmo mês, uma vez que a primeira reunião se encerrou sem nenhum acordo entre as partes ${ }^{4}$, pois enquanto a Embraer afirmava não poder, de forma alguma, considerar a hipótese de reversão das dispensas, os sindicatos condicionaram qualquer tentativa de acordo à reintegração dos empregados dispensados. Como contraproposta, não aceita pelos suscitantes, a Embraer ofereceu uma indenização adicional aos ex-empregados, no valor de $\mathrm{R} \$ 1.600,00$., além da manutenção dos planos de saúde por 12 meses, sem ônus para os funcionários dispensados.

Na nova reunião realizada entre as partes no dia 13 de março de 2009, foram apresentadas pelo Tribunal duas propostas de conciliação: a primeira envolvia a suspensão dos contratos de trabalho por 12 meses, com pagamento de bolsa-qualificação e $20 \%$ dos salários nominais aos trabalhadores, sendo a bolsa paga pelo Fundo de Amparo ao Trabalhador (FAT) durante cinco meses, e o restante, como também os salários, pagos pela Embraer; a segunda proposta manteria as dispensas, com o estabelecimento de uma verba indenizatória de um salário por ano trabalho, com limite de 15 vencimentos, para todos os empregados dispensados, sendo estes reconvocados no caso de abertura de novas vagas.

Diante das propostas apresentadas em audiência, a Embraer afirmou já ter oferecido aos empregados dispensados o pagamento de um adicional de dois salários mensais,

caso, e também por ingressar num campo de estudo muito mais amplo do que o presente trabalho propõe, não serão realizadas maiores considerações sobre o tema.

4 Diante da suspensão das dispensas e da falta de acordo com os sindicatos, a empresa impediu os exempregados de movimentarem suas contas de FGTS, afirmando que a liminar concedida não estabelecia a reintegração ao emprego dos dispensados, e tampouco determinava garantia de emprego ou salários durante o período de sua vigência. 
no teto de até sete mil por pessoa, além da garantia de assistência médica por 12 meses. Porém, tal proposta igualmente não foi aceita pelos suscitantes.

Restando assim mais uma vez frustrada a tentativa de acordo entre as partes, o caso foi posto na pauta extraordinária de julgamento da Seção de Dissídios Coletivos do dia 18 de março de 2009, do TRT da $15^{\text {a }}$ Região, sendo o Desembargador José Antonio Pancotti o relator sorteado do processo.

\subsection{Julgamento do dissídio coletivo pelo TRT da $15^{\mathrm{a}}$ Região}

No julgamento do dissídio, o TRT da $15^{\text {a }}$ Região decidiu por manter as dispensas realizadas, acatando a proposta feita pela Embraer na última audiência de conciliação, determinando que esta deveria pagar, além de todos os direitos trabalhistas devidos, uma indenização no valor de dois salários equivalentes ao aviso prévio, limitado o valor a sete mil reais por empregado, além da manutenção do plano de assistências médica por 12 meses, sem ônus para os dispensados.

Os Desembargadores que compõem a Seção de Dissídios Coletivos do TRT de Campinas seguiram o voto do Desembargador relator José Antonio Pancotti, no sentido de considerarem abusivas as dispensas realizadas pela empresa, sem que antes houvesse uma tentativa de acordo ou negociação com os sindicatos, mesmo que reconheçam não haver obrigação legal determinando tal conduta.

Conforme expôs o Desembargador relator em seu voto:

Neste contexto, havendo pedido dos suscitantes de que se declare a nulidade da dispensa coletiva reputo-a abusiva por falta de boa fé objetiva, nos termos do art. 422 do Código Civil, por ausência de negociação prévia, espontânea e direta entre as partes, que revela falta de lealdade da conduta, na medida em que houve tentativa de conciliação tão-somente com mediação judicial e, 
assim mesmo, por força de uma liminar de suspensão dos efeitos das demissões ${ }^{5}$.

Embora tenha o tribunal considerado que a gravidade da crise econômica mundial tornou a dispensa coletiva uma medida irreversível para a sobrevivência da empresa, este afirmou que:

[...] o condenável foi a forma como a demissão coletiva foi conduzida e efetivada, sem que se tenha buscado formas efetivas de suavização dos seus efeitos, como medidas alternativas, e o que é pior, como já ressaltado acima, não houve anúncio prévio, nem manifestação de disposição de negociar uma demissão coletiva de modo a causar um impacto menor nas famílias e na comunidade ${ }^{6}$.

Dessa forma, destaca o tribunal a importância da negociação coletiva e da atuação sindical na proteção e garantia dos direitos dos trabalhadores, notadamente em realidades como as do caso Embraer, onde "não se pode reconhecer discricionariedade absoluta do empregador para as demissões coletivas, sem que haja uma ampla negociação com os entes sindicais respectivos ${ }^{7}$ ".

Com isso, expõe o Desembargador relator:

$\mathrm{O}$ decreto de abusividade tem por fundamento os princípios gerais e os princípios fundamentais consagrados na Constituição da República, como $a$ dignidade da pessoa humana; os valores sociais do trabalho e da livre iniciativa (no art. $1^{\circ}$, III e IV); a construção de uma sociedade livre, justa e solidária; a garantia do desenvolvimento econômico; a erradicação da pobreza e da marginalização e a redução das desigualdades sociais e regionais; a promoção do bem de todos, sem preconceitos de origem, raça, sexo, cor, idade e quaisquer outras formas de discriminação (no art. $3^{\circ}$, I, II, III e IV); a independência nacional e a prevalência dos direitos humanos

\footnotetext{
${ }^{5}$ TRIBUNAL REGIONAL DO TRABALHO DA $15^{\text {a }}$ REGIÃO. Seção de Dissídios Coletivos. Processo 003092009-000-15-00-4. Decisão 000333/2009-PADC, voto do Desembargador relator, p. 40. Publicado em 30/03/2009.

${ }^{6}$ TRIBUNAL REGIONAL DO TRABALHO DA $15^{\mathrm{a}}$ REGIÃO. Seção de Dissídios Coletivos. Processo 003092009-000-15-00-4. Decisão 000333/2009-PADC, voto do Desembargador relator, p. 38-39. Publicado em 30/03/2009.

${ }^{7}$ TRIBUNAL REGIONAL DO TRABALHO DA $15^{\mathrm{a}}$ REGIÃO. Seção de Dissídios Coletivos. Processo 003092009-000-15-00-4. Decisão 000333/2009-PADC, voto do Desembargador relator, p. 40. Publicado em $30 / 03 / 2009$.
} 


$$
\left(\operatorname{art.} 4^{\text {a }} \text { I e II }\right)^{8} \text {. }
$$

Ainda de acordo com o relator, a falta de uma legislação específica sobre a dispensa coletiva no ordenamento jurídico nacional levou às controvérsias na decisão desde a primeira audiência de conciliação, uma vez que as normas que ensejam a proteção da relação de emprego quanto à dispensa individual "são insuficientes para fazer frente à gravidade do fenômeno da dispensa coletiva"”,

Assim, embora mantidas as dispensas, uma vez que o TRT entendeu inexistir garantia de emprego ou de estabilidade que justificasse a reintegração dos empregados, estas somente poderiam ser efetivadas a partir do dia 13 de março de 2009, data da última audiência de conciliação, ou seja, o contrato dos empregados dispensados seria prorrogado até essa data, para os efeitos trabalhistas.

\subsection{Recurso ao TST}

Insatisfeita com a decisão do TRT de considerar abusiva a dispensa coletiva realizada pela empresa e de prorrogar até o dia 13 do março os contratos de trabalho dos cerca de 4.300 empregados dispensados, a Embraer interpôs Recurso Ordinário ao Tribunal Superior do Trabalho, requerendo a suspensão da sentença proferida pelo TRT da $15^{\mathrm{a}}$ Região até o julgamento final do caso pelo TST.

De acordo com a empresa, que considera que a decisão de suspender as dispensas efetuadas extrapolou os limites da competência do TRT da $15^{\text {a }}$ Região e implicou em tumulto e abuso à ordem processual, as dispensas não podem ser consideradas como

\footnotetext{
${ }^{8}$ TRIBUNAL REGIONAL DO TRABALHO DA $15^{\text {a }}$ REGIÃO. Seção de Dissídios Coletivos. Processo 003092009-000-15-00-4. Decisão 000333/2009-PADC, voto do Desembargador relator, p. 40-41. Publicado em $30 / 03 / 2009$.

${ }^{9}$ TRIBUNAL REGIONAL DO TRABALHO DA $15^{\text {a }}$ REGIÃO. Seção de Dissídios Coletivos. Processo 003092009-000-15-00-4. Decisão 000333/2009-PADC, voto do Desembargador relator, p. 37. Publicado em $30 / 03 / 2009$.
} 
abusivas, uma vez que foram justificadas por motivos econômicos relevantes. Além disso, sustenta também a recorrente que pelo conflito em questão se tratar de um dissídio coletivo de natureza jurídica, a decisão do Tribunal deveria ser meramente declaratória, não cabendo determinar a medida suspensiva.

O Ministro Presidente do TST, Milton de Moura França, embora considerando como "inquestionavelmente dramática a situação dos empregados dispensados ${ }^{10,}$, destacou que a requerente ainda mantém expressivo número de empregados, e afirma que a dispensa coletiva se mostrou uma medida inevitável, diante da realidade econômica atual, e necessária para assegurar a capacidade produtiva da empresa, e, conseqüentemente, manter o emprego dos milhares de empregados restantes.

Segundo o Ministro:

[...] em pleno regime democrático e de direito, a observância fiel ao regramento constitucional e legal é garantia de todos. Independentemente de crises, por mais graves que sejam, é fundamental que todos, sem exceção, submetam-se a normatização vigente, sob pena de fragilização dos direitos e garantias individuais e coletivos que a ordem jurídica constitucional procura proteger $^{11}$.

Assim, de acordo com Ministro Milton de Moura França, não se sustenta o argumento de que a Embraer tenha ofendido o princípio da dignidade da pessoa humana, em especial a dos seus trabalhadores dispensados, visto que o regular exercício de atividade econômica reveste-se também de proteção constitucional, e que a empresa tampouco tenha violado o preceito do art. $7^{\circ}$, inciso I, da Constituição, uma vez que este ainda carece de regulamentação.

\footnotetext{
10 TRIBUNAL SUPERIOR DO TRABALHO. Ministro Presidente do TST, Milton de Moura França. Processo: AG-ES - 207660/2009-000-00-00.7, Divulgado no DEJT 14-04-2009.

11 TRIBUNAL SUPERIOR DO TRABALHO. Ministro Presidente do TST, Milton de Moura França. Processo: AG-ES - 207660/2009-000-00-00.7, Divulgado no DEJT 14-04-2009.
} 
Em relação à questão da negociação coletiva, aponta o Ministro que o argumento utilizado pelo TRT de Campinas para considerar abusivas as dispensas, qual seja, o de que a requerente deveria ter negociado previamente com o sindicato profissional, também não procede, uma vez que não há nenhum dispositivo normativo que obrigue tal conduta.

Com isso, conclui o Ministro Presidente do TST que a requerente nada mais fez do que exercitar seu direito de legitimamente denunciar contratos de trabalho, em observância estrita das leis vigentes, com pagamento de todas as verbas devidas, tendo assim seu pedido deferido, concedendo-se efeito suspensivo ao recurso ordinário até seu final julgamento pelo Tribunal.

Analisado todo o desenvolvimento do caso até então, desde as condições e fatos que originaram o conflito, até apreciação e julgamento do dissídio pelo TRT da $15^{\mathrm{a}}$ Região, e da inicial manifestação do TST, cabe agora passar para o estudo das principais questões jurídicas controvertidas suscitadas nesse debate judicial. 


\section{O PODER DO EMPREGADOR A PARTIR DA CONSTITUIÇÃO FEDERAL DE 1988}

Antes de se proceder à discussão central do estudo aqui proposto, é preciso buscar esclarecer qual é o real poder que detém o empregador dentro da realidade jurídica nacional e quais os principais fundamentos - sejam jurídicos, políticos ou econômicos - da atribuição desse poder, além das críticas existentes.

Para tanto, é necessária a análise, à luz da Constituição Federal de 1988, de questões essenciais ao debate, como o modelo do FGTS, universalizado por esta Carta Magna e que trouxe maior flexibilização para o mercado de trabalho ao extinguir a efetiva estabilidade no emprego, e a real dimensão do poder diretivo do empregador, previsto na CLT, afirmando que o poder de dispensa do empregador não é absoluto e encontra limitações nos princípios constitucionais de proteção à relação de trabalho e à pessoa do trabalhador.

\subsection{O FGTS e a liberalização do mercado de trabalho}

De acordo com Maurício Godinho Delgado, desde a instauração do modelo justrabalhista tradicional do país, nas décadas de 1930 e 1940, a figura da extinção do contrato de trabalho sofreu intensas transformações, essencialmente no que tange ao exercício unilateral, pelo empregador, da faculdade de rompimento do contrato de trabalho. Como aponta o autor:

A diferenciação de tratamento jurídico, neste aspecto, permite, assim, vislumbrar-se três períodos básicos no sistema brasileiro: o antigo modelo jurídico celetista; o modelo liberal inaugurado pelo FGTS, mas que conviveu até 5.10.1988, com o velho sistema da CLT; e, finalmente, a fase jurídica regulada pela Carta Constitucional de $1988 .{ }^{12}$

\footnotetext{
${ }^{12}$ DELGADO, Maurício Godinho. Curso de direito do trabalho, 5.ed., São Paulo: LTr, 2006, p. 1110.
} 
O FGTS (Fundo de Garantia por tempo de serviço), criado pela Lei n.

5.107/66, e hoje regulado pela Lei n. 8.036/90, nasceu ainda na época do regime autoritário no país, como uma espécie de alternativa ao tão criticado sistema estabilitário celetista que então vigorava. Tais críticas se davam, principalmente, em razão de sua excessiva rigidez e forte contingenciamento à vontade empresarial, pois fixava significativos óbices à ruptura do contrato de trabalho pelo empregador.

Esse modelo celetista, baseado essencialmente no princípio da continuidade da relação de emprego, e acolhido inteiramente pela Carta Constitucional de $1946^{13}$, era formado pela combinação de duas sistemáticas primordiais, como explica Delgado:

[...] em primeiro lugar, a presença de indenizações crescentes em virtude do tempo de serviço, em situações de dispensas desmotivadas anteriores a dez anos (antigos artigos 477 e 478, caput, CLT, hoje tacitamente revogados); em segundo lugar, a presença da estabilidade no emprego, após dez anos de serviço junto ao mesmo empregador - prazo que foi jurisprudencialmente reduzido para efetivos nove anos de serviço (art. 492, CLT; antigo Enunciado 26, TST) ${ }^{14}$.

Cumpre ressalvar que esse antigo regime de extinção contratual da CLT não impunha impedimento jurídico - ressalvados os casos de estabilidade provisória - quanto à ruptura desmotivada do contrato de trabalho pelo empregador, desde que tal contrato tivesse duração inferior a dez $\operatorname{anos}^{15}$, mas somente apresentava reais obstáculos econômico-

\footnotetext{
${ }^{13}$ Mais precisamente, por seu art. 157, inciso XII, que determinava: "Art 157 - A legislação do trabalho e a da previdência social obedecerão nos seguintes preceitos, além de outros que visem a melhoria da condição dos trabalhadores: (...)XII - estabilidade, na empresa ou na exploração rural, e indenização ao trabalhador despedido, nos casos e nas condições que a lei estatuir;". De acordo com Luiz Werneck Vianna, este dispositivo da Constituição de 1946 nasceu de um processo de quase duas décadas que buscou consolidar a estabilidade no emprego como um direito elementar do trabalhador.

${ }^{14}$ DELGADO, Maurício Godinho. Curso de direito do trabalho, p. 1110.

${ }^{15}$ Nos contratos de trabalho superiores a dez anos, no entanto, havia um óbice jurídico propriamente dito, exposto nos arts. 492 e 500 da CLT, no sentido que não mais se permitia o rompimento sem justa causa do contrato pelo empregador. Porém, aponta Vianna, havia uma verdadeira corrupção desse instituto da estabilidade, no sentido que o empregado, injustamente afastado de seu emprego, não tinha o efetivo direito à reintegração determinado pela lei, visto que este direito era convertido numa indenização por tempo de serviço uma vez que se provasse a incompatibilidade entre empregado e empregador (e tal incompatibilidade passou a ser presumida, ao invés de compor matéria de prova).
} 
financeiros a esta prática, dentro da premissa de buscar dar efetividade ao princípio da continuidade da relação de emprego ${ }^{16}$.

Porém, diversas críticas insurgiam contra essa sistemática, provenientes principalmente das grandes empresas, que ambicionavam uma liberalização do mercado de trabalho, no sentido de ampliar o seu poder empregatício e permitir um maior fluxo de mãode-obra. Dentre as principais críticas a esse modelo celetista, destaca-se a de que este nem sequer previa a possibilidade de dispensas seletivas justificadas por circunstancias econômicas, financeiras e tecnológicas que afetassem, comprovadamente, a estrutura e dinâmica das empresas.

Tais críticas encontraram, dentro do regime ditatorial nacional, um terreno propício para seu crescimento e força, uma vez que este novo regime, além de silenciar seus opositores, apresentava como discurso oficial o desenvolvimento de uma forte política econômica. Nesse contexto, teoricamente como uma alternativa ao sistema celetista da CLT ${ }^{17}$, criou-se o modelo do FGTS no país.

Dentro da nova sistemática trazida pelo FGTS, o empregador teria que depositar mensalmente o montante referente a $8 \%$ da remuneração que cabia ao seu empregado, tendo esse, no caso de dispensa imotivada, o direito de sacar o valor depositado nesse Fundo, com um acréscimo percentual rescisório de $10 \%$ sobre o valor total, realizadas as devidas correções monetárias. No entanto, ao optar expressamente por este modelo do Fundo de Garantia, na época da celebração do contrato, o empregado renunciava ao antigo

\footnotetext{
${ }^{16}$ Como expõe Luiz Werneck Vianna, "o legislador declarava sua intenção de limitar a liberdade do capital na contratação da força de trabalho. Um grupo de trabalhadores, aos quais a lei outorgava estabilidade, passava a ser protegido das oscilações do mercado."(VIANNA, Luiz Werneck. Liberalismo e sindicato no Brasil. 4ed.,Belo Horizonte: Ed. UFMG, 1999, p. 339).

${ }^{17}$ Diz-se teoricamente porque, na realidade, os empregadores forçavam seus empregados a optarem pelo modelo do FGTS na celebração do contrato.
} 
modelo de estabilidade no emprego, não estando mais protegido pelo obstáculo jurídico que impedia a dispensa sem justa causa após dez anos de serviço.

A implementação desse novo regime jurídico, que promoveu a liberalização econômica do mercado de trabalho, visou a atender os interesses das grandes empresas, que buscavam criar uma flexibilização nas relações de emprego, diminuindo ou obliterando os obstáculos jurídicos, econômicos e financeiros ao exercício de seu poder diretivo, principalmente em relação à possibilidade de dispensa arbitrária $^{18}$, e também do governo militar, que ambicionava criar uma atmosfera de euforia e desenvolvimento, e conseqüente satisfação com o regime, através da obtenção de favoráveis índices de crescimento econômico no país.

\section{Conforme expõe Delgado:}

A sistemática do Fundo de Garantia não apenas retirou limites jurídicos às dispensas desmotivadas (no sistema do Fundo, repita-se, não seria mais possível, juridicamente, o alcance da velha estabilidade celetista), como também reduziu, de modo significativo, o obstáculo econômico-financeiro às rupturas de contratos inferiores a nove/dez anos, substituindo-se pela sistemática pré-constituída dos depósitos mensais do FGTS ${ }^{19}$.

Mesmo diante dessa flagrante realidade, as Constituições brasileiras seguintes, de 1967 e 1969, absorveram, sem grandes controvérsias, essa nova sistemática, embora ainda prevendo-a como uma alternativa ao ainda existente modelo de estabilidade celetista. Porém, o mercado de trabalho, a essa época, já se apresentava bastante submetido ao modelo do FGTS.

\footnotetext{
${ }^{18}$ Ainda assim, a Súmula 98 do TST, de 1980, determinou que a equivalência entre dos regimes do FGTS e da estabilidade prevista na CLT é meramente jurídica, e não econômica, não sendo cabível o direito de indenização a título de reposição de diferenças.

${ }^{19}$ DELGADO, Maurício Godinho. Curso de direito do trabalho, p. 1112.
} 
Nesse contexto, da ampliação do sistema do Fundo de Garantia para a quase totalidade dos empregados, a Constituição Federal de 1988 pôs fim à dualidade de regimes jurídicos existentes quanto à questão da extinção do contrato de trabalho, eliminando o antigo modelo de estabilidade presente na CLT $^{20}$ e universalizando o FGTS. Dessa forma, o empregado, na celebração do contrato, não mais realizava a opção escrita de qual modelo jurídico deveria reger seu contrato, pois o FGTS figuraria agora como um direito inerente a todo contrato empregatício, de acordo com o art. $7^{\circ}$, inciso III da nova Constituição.

Entretanto, conforme afirma Delgado, não se pode concluir que a Constituição, através dessa universalização da sistemática do Fundo de Garantia, tenha realizado uma opção política liberal em relação ao tema da extinção do contrato de trabalho, pois, ao lado dessa modificação, o legislador constituinte estabeleceu "preceito instigador da busca de novo sistema de regulação das rupturas contratuais por ato empresarial ${ }^{21}$.”.

Dessa forma, não se pode afirmar que a Constituição, nesse contexto, tenha buscado permitir a realização de dispensa arbitrária sem qualquer tipo de limitação jurídica, pois o próprio texto constitucional expõe diversos princípios que destacam a importância e primazia conferida ao trabalho e as inúmeras garantias atribuídas ao empregado ${ }^{22}$, na figura de titular desses direitos.

\footnotetext{
${ }^{20}$ Extinguindo assim tanto o aspecto indenizatório como o de estabilidade dessa antiga sistemática.

${ }^{21}$ DELGADO, Maurício Godinho. Curso de direito do trabalho, p. 1114.

${ }^{22}$ Segundo Delgado, essa orientação constitucional estaria presente no texto do art. $7^{\circ}$, inciso I, que determina a garantia de "relação de emprego protegida contra despedida arbitrária ou sem justa causa, nos termos de lei complementar, que preverá indenização compensatória, dentre outros direitos", no inciso XXI do mesmo artigo, que estabelece "aviso prévio proporcional ao tempo de serviço, sendo no mínimo de trinta dias, nos termos da lei", além da regra fixada pelo art. 10, II, do ADCT, que prevê que "até que seja promulgada a lei complementar a que se refere o art. $7^{\circ}$, I, da Constituição [...] fica limitada a proteção nele prevista ao aumento, para quatro vezes, da porcentagem prevista no art. $6^{\circ}$, caput e parágrafo 1 , da Lei n. 5.107, de 13 de setembro de 1966". Além desses dispositivos, observa-se ainda a existência de demais preceitos constitucionais que reforçam essa posição, como o exposto no art. 1, inciso IV, que estabelece como um dos fundamentos da República Federativa do Brasil os valores sociais do trabalho. Além disso, a mesma Constituição ainda determina que, tanto a ordem social como a própria ordem econômica, devem se fundar na
} 
Para Delgado, citando o constitucionalista José Afonso da Silva, esses preceitos constitucionais traduzem a verdadeira existência de um "direito social ao trabalho, como condição da efetividade da existência digna (fim da ordem econômica) e, pois, da dignidade da pessoa humana, fundamento, também, da República Federativa do Brasil ${ }^{23}$ ".

Com isso, observa Delgado, deve-se atentar que a Constituição Federal de 1988 buscou, a partir do expresso repúdio à realização da dispensa arbitrária, resgatar a importância do princípio da continuidade da relação de emprego e reinserir tal princípio como pilar harmônico para a ordem justrabalhista, na tentativa de se construir um novo modelo ou sistemática de regulação referente à extinção contratual ${ }^{24}$.

Nesse contexto, observadas as mudanças introduzidas pelo modelo do FGTS - universalizado pela Constituição de 1988 - quanto à possibilidade de ruptura unilateral do contrato de trabalho pelo empregador, cabe agora analisar qual é a verdadeira dimensão do poder empregatício na relação de trabalho, verificando se no âmbito deste poder se insere a realização de dispensa arbitrária, seja individual ou coletiva, sem qualquer tipo de limitação.

\subsection{Aspectos do poder diretivo}

De acordo com o art. $2^{\circ}$, caput, da CLT: "Considera-se empregador a empresa, individual ou coletiva, que, assumindo os riscos da atividade econômica, admite, assalaria e dirige a prestação pessoal de serviço". Tal dispositivo não só traz uma definição de empregador, cuja noção jurídica é essencialmente relacionada à noção de empregado - posta

valorização e primado do trabalho - artigos. 170 e 193 (DELGADO, Maurício Godinho. Curso de direito do trabalho p. 1114-1115).

${ }^{23}$ DELGADO, Maurício Godinho. Curso de direito do trabalho, p. 1115.

${ }^{24}$ Para Delgado, dessa forma, a Constituição atual apresenta um modelo ainda transitório para a regulação desse aspecto, ou ainda, apresenta as bases jurídicas onde deve se assentar a nova sistemática a ser desenvolvida nesse sentido (DELGADO, Maurício Godinho. Curso de direito do trabalho, p. 1115). 
no artigo imediatamente seguinte - como também apresenta a idéia do chamado poder diretivo do empregador, representado pelo poder de dirigir a prestação pessoal de serviço.

A relação entre empregado e empregador traduz-se numa relação de direito, uma vez que se estabelece por meio de um contrato de trabalho, e assim atribuiria ao empregador o direito, e não o poder, de direção do serviço. No entanto, como afirma Márcio Túlio Viana, toda relação de direito se consubstancia numa relação de poder, pois há sempre a imposição de uma vontade sobre a outra, no caso, da vontade do empregador sobre a do empregado $^{25}$.

Embora tal relação de poder se encontre presente em todos os campos do Direito, é no Direito do Trabalho, mais especificamente na relação de emprego, que se manifesta de forma mais visível e direta, principalmente devido à desigualdade material entre os contratantes ${ }^{26}$. No dizer de Delgado:

\begin{abstract}
O poder no âmbito do estabelecimento e da empresa traduz-se em uma das manifestações mais relevantes do fenômeno do poder no contexto societário que se conhece na sociedade contemporânea. É certamente uma das manifestações do fenômeno global do poder em que este se estruturou em bases mais assimétricas, unilaterais e rígidas dentre todas as manifestações que despontam como características da sociedade ocidental dos últimos dois séculos. Tão marcante era a assimetria que não apenas permitiu a cunhagem do epíteto 'despotismo de fábrica', como referência paradigmática a tal estrutura e dinâmica de poder, como, também induziu, em certo instante, a se concluir trata-se tal despotismo de característica atávica ao sistema de organização da produção e do trabalho na presente sociedade ${ }^{27}$.
\end{abstract}

No entanto, o poder diretivo é um instrumento de grande importância para o empregador, no sentido de que o desenvolvimento e sucesso de seu empreendimento dependem, essencialmente, das atividades desempenhadas pelos seus empregados. Dessa

\footnotetext{
${ }^{25}$ VIANA, Márcio Túlio. Poder diretivo e sindicato: entre a opressão e a resistência. Os novos horizontes do direito do trabalho: homenagem ao Ministro José Luciano de Castilho Pereira. São Paulo: Ltr, 2005, p. 384.

${ }^{26} \mathrm{O}$ empregador, possuidor dos meios de trabalho, e o empregado, geralmente hipossuficiente.

${ }^{27}$ DELGADO, Maurício Godinho. O poder empregatício. São Paulo: LTr, 1996, p. 194.
} 
forma, é imprescindível que o empregador possa dirigir tais atividades, buscando orientá-las e ajustá-las para atingir uma maior eficiência e perseguir o fim pré-determinado.

De acordo com Messias da Silva, existem várias teorias que buscam fundamentar esse poder diretivo, sendo a chamada "teoria contratualista" a mais aceita pela doutrina. Segundo tal teoria, "o poder de direção encontra suporte no contrato de trabalho, ajuste de vontades no qual o empregado espontaneamente se põe em posição de subordinação, aceitando a direção da sua atividade pelo empregador ${ }^{28}$ ".

No mesmo sentido, aponta Delgado, citando Nélio Reis:

Não há dúvida de que economicamente e até que se opere uma transformação no regime capitalista em que vivemos, o patrão é o dono da empresa compreendida no seu todo perfeito. Mas a integração nesta dos trabalhadores não se opera pelo direito de propriedade, e, sim, pela via contratual, à semelhança das ligações entre a empresa e outros organismos da vida social ${ }^{29}$.

Essa fundamentação traz a idéia da subordinação do empregado como contraface do poder diretivo, ou seja, que essa subordinação seria um pressuposto para o empregador exercer efetivamente o seu poder de direção. Segundo Túlio Viana, a acepção mais aceita hoje pela doutrina é a de que tal subordinação seria meramente jurídica ${ }^{30}$, sendo

28 MESSIAS DA SILVA. Leda Maria. Poder diretivo do empregador, emprego decente e direitos da $\begin{array}{lll}\text { personalidade. } & \text { Disponível em }\end{array}$ <http://www.cesumar.br/mestradodireito/arquivos/volume6/Poder\%20diretivo.pdf> Acesso em: 10 de junho, 2009, p. 271.

${ }^{29}$ DELGADO, Maurício Godinho, O poder empregatício, p. 171.

30 A subordinação jurídica ou dependência hierárquica, conforme ensina Mozart Victor Russomano, "é puramente contratual, sem caráter pessoal, reconhecida por leis combinadas, que ao mesmo tempo obrigam o empregado à subordinação e impedem o abuso desse poder pelo empregador." (MESSIAS DA SILVA. Leda Maria. Poder diretivo do empregador, emprego decente e direitos da personalidade, p. 272). 
que demais dependências, como a técnica ou econômica, seriam apenas secundárias ou ocasionais, embora se visualizem freqüentemente ${ }^{31}$.

Contudo, embora se diga que a subordinação seja apenas jurídica, argumentando-se que nem sempre se pode verificar outras dependências do empregado em relação ao empregador ${ }^{32}$, na realidade isso não é uma verdade. Como expõe Túlio Viana:

Mas a verdade é que - em última análise e em termos globais - a dependência é sempre econômica, na medida em que os empregados, não possuindo os meios de produção, têm de produzir por conta alheia. E também é sempre técnica, já que o empresário, detendo em suas mãos aqueles meios - inclusive a força-trabalho - deles dispõe de forma articulada e racional, segundo os seus próprios critérios. [...] Naturalmente, a dependência é também jurídica. Não só no sentido de que o direito a regula, fixando os seus limites, mas no sentido de que a legitima. Na verdade, são exatamente aqueles limites que a legitimam ${ }^{33}$.

Reginaldo Melhado explica que, para Weber, a dominação legítima, como uma relação de mando, "pressupõe uma determinada capacidade de escolha e portanto

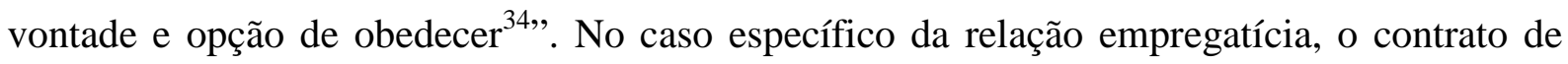
trabalho seria o fundamento da relação de poder e sujeição, pois é através dele que o empregado, por consentimento próprio, se vincula à figura do empregador.

Porém, Melhado afirma, no mesmo entender de Túlio Viana, que o regime econômico capitalista busca sedimentar a idéia da existência de uma subordinação somente jurídica, e negando a incidência de elementos extracontratuais de dependência, possibilitando assim a legitimação do poder do empregador pelo próprio direito. Dessa forma:

\footnotetext{
${ }^{31}$ VIANA, Márcio Túlio. Poder diretivo e sindicato: entre a opressão e a resistência. Os novos horizontes do direito do trabalho: homenagem ao Ministro José Luciano de Castilho Pereira, p. 385.

32 Esses exemplos seriam casos raros, como o do empregado que possui condições financeiras para sua sobrevivência mesmo sem trabalhar, ou do empregado altamente especializado. Tais hipóteses, porém, se mostram como verdadeiras exceções à regra de que a subordinação se apresenta em três aspectos: técnica, econômica e jurídica.

${ }^{33}$ VIANA, Márcio Túlio. Poder diretivo e sindicato: entre a opressão e a resistência. Os novos horizontes do direito do trabalho: homenagem ao Ministro José Luciano de Castilho Pereira, p. 386.

${ }^{34}$ MELHADO, Reginaldo. Poder e sujeição: os fundamentos da relação de poder entre capital e trabalho e o conceito de subordinação. São Paulo: LTr, 2003, p. 205.
} 
Os trabalhadores agora, no capitalismo, são 'livres', e esse simulacro de liberdade dá status de racionalidade à sua submissão ao capital: há uma eleição voluntária que é inteiramente livre, no plano jurídico, mas rigorosamente coercitiva, no âmbito real em que a relação se dá. O negócio pelo qual o trabalhador vende sua capacidade de trabalho é um ato jurídico cerebral, alicerçado em uma postura de ponderação, de racionalidade. $\mathrm{O}$ problema é que a especificidade das regras de mercado em que se realiza o intercambio não permite ao empregado condições estratégias isonômicas. Antes, há um desequilíbrio estrutural que se desdobra em um conflito social e político insolúvel ${ }^{35}$.

Conforme exposto de forma pacífica pela doutrina trabalhista, o poder diretivo do empregador incide - ou deve incidir - tão somente sobre a atividade desempenhada pelo empregado, e não sobre a pessoa deste ${ }^{36}$. Assim sendo, haveria apenas uma subordinação objetiva, e não subjetiva, pois o empregado estaria no contrato cedendo sua força de trabalho, e seria somente sobre esta que o empregador teria o poder de direção. Porém, conforme explica Túlio Viana, essa afirmação indica apenas que a relação de poder não pode extrapolar o campo do trabalho, mas não significa que dentro deste campo este poder não incida sobre a pessoa do empregado, pois não há como realmente separar este de sua força motriz ${ }^{37}$.

É preciso atentar também para a diferenciação existente entre o poder diretivo e o chamado direito de cobrança. O direito de cobrança está presente em todas as espécies de contrato, não só o trabalhista, e representa o direito de uma das partes contratuais de cobrar da outra o cumprimento daquilo que foi contratado, ou seja, do que dispõe expressamente o contrato. O poder diretivo, característico do contrato trabalhista, apresenta

\footnotetext{
${ }^{35}$ MELHADO, Reginaldo. Poder e sujeição: os fundamentos da relação de poder entre capital e trabalho e o conceito de subordinação, p. 210.

${ }^{36}$ Cabe aqui observar, conforme atenta Messias da Silva, que a manifestação do poder diretivo pode ser visualizada dentro de três diferentes aspectos ou dimensões: um poder organizacional, um poder disciplinar e um poder regulamentar. O primeiro, também chamado por alguns doutrinadores de poder diretivo stricto sensu, corresponde ao poder do empregador de organizar seu negócio, determinando, por exemplo, qual a espécie de atividade deseja desempenhar, o tipo de sociedade, o número de empregados, o local e o horário de trabalho e o regulamento da empresa. O segundo, poder disciplinar, diz respeito ao poder de impor sanções aos empregados, seja através de advertências - figura sem previsão legal - ou por meio de suspensão, prevista no art. 474 da CLT. O terceiro e último, poder regulamentar, refere-se ao poder do empregador de fiscalizar as atividades profissionais desenvolvidas por seus empregados, buscando assegurar eficiência, qualidade e quantidade (MESSIAS DA SILVA. Leda Maria. Poder diretivo do empregador, emprego decente e direitos da personalidade, p. 275).

${ }^{37}$ VIANA, Márcio Túlio. Poder diretivo e sindicato: entre a opressão e a resistência. Os novos horizontes do direito do trabalho: homenagem ao Ministro José Luciano de Castilho Pereira, p. 387.
} 
uma peculiaridade: representa o direito do empregador de exigir tudo aquilo que não foi ajustado.

Assim, o empregador, na prerrogativa de dirigir a prestação pessoal do serviço, pode exigir do empregado condutas que não foram expressamente previstas no contrato de trabalho, desde que tais condutas, logicamente, estejam relacionadas ao serviço para o qual o empregado foi contratado para realizar ${ }^{38}$.

Dessa forma, destaca Viana:

[...] o poder diretivo, pelo menos em termos lógicos, não precisa de um contrato para se manifestar. Mas o contrato é útil para legitimá-lo, pois sugere que foi o trabalhador, livremente, quem decidiu perder a liberdade.

Naturalmente, o contrato também o restringe. Assim, por exemplo, não pode o empregador exigir que o empregador trabalhe em função diferente da que foi combinada ${ }^{39}$.

\subsubsection{Poder diretivo e atuação sindical}

A idéia do poder diretivo como um poder potestativo do empregador não mais se apresenta coerente com a realidade jurídica atual ${ }^{40}$, pois se mostra incapaz de assimilar e responder ao processo de conquista democrática da empresa vivenciado ao longo do século $\mathrm{XX}^{41}$.

\footnotetext{
${ }^{38}$ Como exemplifica Viana: “[...] não é o poder de dizer a um motorista: 'trabalhe como motorista, como nós contratamos'. É o direito de lhe dizer: 'hoje, você vai trabalhar nessa linha, e amanhã em outra, pois foi isso que eu decidi'" (VIANA, Márcio Túlio. Poder diretivo e sindicato: entre a opressão e a resistência. Os novos horizontes do direito do trabalho: homenagem ao Ministro José Luciano de Castilho Pereira, p. 387).

${ }^{39}$ VIANA, Márcio Túlio. Poder diretivo e sindicato: entre a opressão e a resistência. Os novos horizontes do direito do trabalho: homenagem ao Ministro José Luciano de Castilho Pereira, p. 388.

${ }^{40}$ Da mesma forma, destaca Delgado, outras concepções sobre o poder diretivo historicamente construídas, como as que concebem este poder como um fenômeno hierárquico e a que afirma ser um "direito-função", também se mostram insuficientes para definir a nova real compreensão desse instituto, uma vez que não conseguem se desvencilhar da idéia de unilateralidade - o titular desse poder seria ainda apenas o empregador (DELGADO, Maurício Godinho. O poder empregatício, p. 185-186).

${ }^{41}$ DELGADO, Maurício Godinho. O poder empregatício, p. 185.
} 
Nesse sentido, uma mais atualizada compreensão desse poder, afastando-se da idéia de um poder potestativo, vem a conferir "o adequado estatuto e intensidade à participação coletiva obreira no interior da relação de poder ${ }^{42 \%}$, favorecendo, assim, o reconhecimento de uma característica singular ao contrato de trabalho: que embora este seja originalmente bilateral, como os demais contratos jurídicos, pode efetivamente vir a se multilateralizar, pela interveniência de outras vontades que compõem a dinâmica empresarial interna.

\section{Como destaca Delgado:}

Um contrato empregatício que se firme entre um sujeito individual e coletivo empresário, de um lado, e um sujeito individual obreiro, de outro lado, pode receber a interveniência, em sua reprodução sócio-jurídica ao longo da relação de emprego, da vontade do sujeito coletivo obreiro, através de suas múltiplas modalidades de organização e atuação [...]. $\mathrm{O}$ contrato empregatício é, portanto, essencialmente dinâmico, nele podendo atuar, após o pacto inicial celebrado, a vontade coletiva obreira, visando garantir o alcance de um processo mais democrático de gestão de poder no contexto empresarial interno ${ }^{43}$.

Assim, a atuação sindical, desde que efetiva, pode funcionar como limitador

do poder de comando do empregador; e um importante limitador, pois, segundo Viana, um dos principais efeitos da fragilização do sindicato - principal fonte material do Direito do Trabalho - é a multiplicação dos casos de fraude e violação à lei, uma vez que as normas de proteção ao trabalhador se fragilizam simultaneamente, ao mesmo tempo em que o poder diretivo se intensifica ainda mais ${ }^{44}$.

Além disso, o poder diretivo encontra também limites nos direitos fundamentais do trabalhador e nos princípios constitucionais de valorização e proteção do

\footnotetext{
${ }^{42}$ DELGADO, Maurício Godinho. O poder empregatício, p. 192.

${ }^{43}$ DELGADO, Maurício Godinho. O poder empregatício, p. 172.

${ }^{44}$ VIANA, Márcio Túlio. Poder diretivo e sindicato: entre a opressão e a resistência. Os novos horizontes do direito do trabalho: homenagem ao Ministro José Luciano de Castilho Pereira, p. 408.
} 
trabalho, como será visto de forma mais aprofundada num capítulo mais à frente. De forma breve, pode-se visualizar inúmeros direitos fundamentais da pessoa humana que, por óbvio, se põem como limites básicos e intransponíveis do poder diretivo, como direito à vida, liberdade, igualdade, segurança, propriedade e privacidade.

No caso Embraer, não houve sequer qualquer tipo de negociação coletiva ou interveniência sindical anterior à realização das dispensas, ferindo a estrutura essencialmente dinâmica do contrato de trabalho, que atribui grande relevância ao papel do sindicato, cuja atuação deve se orientar no sentido de buscar limitar o poder diretivo do empregador, através da garantia do respeito aos direitos fundamentais dos empregados.

Conforme aduz Viana:

Provavelmente, nunca o capital teve tanta ascendência sobre o trabalho, seja em termos individuais (do poder coletivo) como em termos coletivos (do sindicato). E, ainda uma vez, os dois fenômenos interagem. Na medida em que o poder diretivo se acentua, a resistência coletiva se reduz - e viceversa ${ }^{45}$.

Para Delgado, a melhor ou mais adequada concepção do poder diretivo é aquela que concebe este poder como uma relação jurídica contratual complexa. Porém, o importante não é a definição em si, carente de maior complementação, mas justamente a consequiência ou resultado desta, qual seja, o abandono da idéia do poder diretivo como sendo um poder potestativo do empregador e o reconhecimento e identificação do impacto das ações coletivas no poder diretivo.

Entendidos assim os aspectos do poder diretivo relevantes para a discussão aqui proposta, destacando-se a importância da interveniência sindical na proteção dos

\footnotetext{
${ }^{45}$ VIANA, Márcio Túlio. Poder diretivo e sindicato: entre a opressão e a resistência. Os novos horizontes do direito do trabalho: homenagem ao Ministro José Luciano de Castilho Pereira, p. 410.
} 
trabalhadores, limitando o poder de comando do empregador e impedindo seus abusos ou excessos, resta agora, antes de adentrar o debate central do presente estudo, passar a análise da dispensa coletiva em si, apontando seus traços diferenciais e observando seu forte impacto social. 


\section{A DISPENSA COLETIVA DE TRABALHADORES}

A dispensa coletiva, diferentemente da dispensa individual, não encontra regulação específica em nenhuma norma ou dispositivo, constitucional ou infraconstitucional, do ordenamento jurídico nacional. Embora se tenha buscado preencher essa omissão legislativa, com, por exemplo, a ratificação - e posterior denúncia - da Convenção n. 158 da OIT, essa tarefa não foi empreendida com sucesso, permanecendo ainda as grandes controvérsias sobre o tema dentro de um debate doutrinário e judicial.

Ainda que muitas das normas constitucionais e trabalhistas referentes à dispensa individual possam ser aplicadas também para casos de dispensa coletiva, tais normas não se apresentam adequadas para estes casos, uma vez que há uma distinção entre as duas espécies de dispensas, principalmente diante de sua gravidade e seus efeitos.

\subsection{Dispensa coletiva e dispensa plúrima}

Segundo Delgado, a dispensa coletiva é aquela que atinge um grupo ou coletividade de trabalhadores, vinculados a um determinado estabelecimento ou empresa, configurando uma "prática maciça de rupturas contratuais ${ }^{46 "}$. Já a dispensa individual, embora envolva geralmente um único trabalhador, pode atingir também vários empregados, não devendo, porém, nesse aspecto, ser confundida com uma dispensa de caráter coletivo, pois representaria apenas um número disperso de dispensas individuais, e não a prática maciça de rupturas contratuais a que se referiu o autor.

De forma mais clara e precisa, Orlando Gomes, ainda em 1974, buscou apontar as diferenças e os pontos comuns entre a dispensa coletiva e o que ele chamou de

\footnotetext{
${ }^{46}$ DELGADO, Maurício Godinho. Curso de direito do trabalho, p. 1154.
} 
dispensa plúrima. De acordo com o autor, a distinção entre ambas restaria em dois traços particulares: a peculiaridade da causa e a redução definitiva do quadro pessoal.

Assim, para Gomes:

$\mathrm{Na}$ dispensa coletiva é única e exclusiva a causa determinante. $\mathrm{O}$ empregador, compelido a dispensar certo número de empregados, não se propõe a despedir determinados trabalhadores, senão aqueles que não podem continuar no emprego. Tomando a medida de dispensar uma pluralidade de empregados não visa o empregador a pessoas concretas, mas a um grupo de trabalhadores identificáveis apenas por traços não-pessoais, como a lotação em certa seção ou departamento da empresa, a qualificação profissional, ou o tempo de serviço. A causa da dispensa é comum a todos, não se prendendo ao comportamento de nenhum deles, mas a uma necessidade da empresa ${ }^{47}$.

Assim, na dispensa coletiva o objetivo do empregador nunca é o de abrir

mais vagas, ou de buscar substituir os empregados dispensados, mas o de realmente reduzir, em caráter definitivo, o seu quadro de pessoal, seja porque estes se tornaram desnecessários, diante de uma nova direção ou finalidade empresarial, ou porque o empregador atravessa alguma difícil situação econômica e não tem mais condições de conservar todos os seus trabalhadores $^{48}$.

A dispensa plúrima, por outro lado:

[...] há de ser praticada, primeiramente, contra um número considerável de empregados, por fato que a todos diga respeito, como, por exemplo, a insubordinação dos trabalhadores da seção de embalagem de uma empresa. Os dispensados têm de ser pessoas determinadas, constituindo um conjunto concreto de empregados. Afastados, hão de ser substituídos, eis que o serviço precisa ser prestado continuadamente por igual número de

\footnotetext{
${ }^{47}$ GONÇALVES JÚNIOR, Mário. Demissão coletiva. Revista do direito trabalhista. Fevereiro, ano 13, n. 02, Consulex, 2007, p. 11.

48 Da mesma forma, Cláudia Regina Salomão define dispensa coletiva como "a modalidade de rescisão contratual, que envolve mais de um empregado, por um único motivo igual para todos, quase sempre por razões de ordem objetiva da empresa, como problemas financeiros, econômicos e técnicos." (SALOMÃO, Claudia Regina. A dispensa coletiva no ordenamento jurídico brasileiro e a influência da Convenção n. 158 da OIT. Legislação do Trabalho. São Paulo: Abril, ano 72, n. 04, LTr, 2008, p. 444).
} 
trabalhadores. A dispensa plúrima não tem, por último, a finalidade de reduzir o quadro de pessoal ${ }^{49}$.

A dispensa plúrima a que se refere Gomes representaria, nesse sentido, ao que Delgado se referiu como as várias dispensas individuais, distinguindo-se, conforme exposto, da figura da dispensa coletiva.

No entanto, conforme destaca o Desembargador José Antonio Pancotti, relator do processo referente ao caso Embraer no TRT da $15^{a}$ Região:

[...] não há no ordenamento jurídico regramento nenhum acerca da despedida em massa ou coletiva, seja relacionada a uma causa objetiva, de ordem econômico-conjuntural ou técnico-estrutural, ou a uma crise econômica internacional, como a que se vive atualmente, o que acaba por fazer a situação merecer o mesmo tratamento jurídico da proteção da relação de emprego contra a despedida individual sem justa causa, isto é, a situação recebe tratamento como se fosse uma soma de despedidas individuais sem justa causa ${ }^{50}$.

Quanto ao caso Embraer, observa-se que as dispensas foram realizadas

diante de uma única e exclusiva causa determinante ${ }^{51}$, qual seja, a crise econômica mundial que afetou gravemente a indústria de aviação civil. Além disso, a redução do quadro pessoal se deu em caráter definitivo, justamente diante da alegada necessidade da empresa em diminuir seus gastos para manter sua capacidade produtiva frente à crise atual.

\footnotetext{
${ }^{49}$ GONÇALVES JÚNIOR, Mário. Demissão coletiva. Revista do direito trabalhista, p. 11.

50 TRIBUNAL REGIONAL DO TRABALHO DA 15ª REGIÃO. Seção de Dissídios Coletivos. Processo 003092009-000-15-00-4. Decisão 000333/2009-PADC, voto do Desembargador relator, pg. 31. Publicado em $30 / 03 / 2009$.

${ }^{51}$ É importante observar que, na dispensa coletiva, embora se diga que os empregados são dispensados diante de uma causa única e exclusiva, não visando o empregador atingir pessoas concretas, na prática esta medida pode esconder dispensas discriminatórias. Dessa forma, o empregador, aproveitando-se da realização da dispensa coletiva, pode vir a dispensar determinado empregado, identificado por traços pessoais, uma vez que tal dispensa poderia passar despercebida se inserida dentro do contexto da dispensa coletiva. Nesse ponto, destaca-se também a necessidade de limitação da prática da dispensa coletiva, revelando a importância do papel desempenhado pelo sindicato, conforme será analisado mais à frente, no sentido também de, uma vez não evitadas as dispensas, impedir tais abusos.
} 


\subsection{Efeitos da dispensa coletiva}

Não é tão somente no aspecto conceitual que ocorre a distinção entre dispensa coletiva e dispensa individual, mas ambas as espécies de dispensa se diferenciam também pelos seus efeitos. Enquanto a dispensa individual se apresenta de forma mais branda, ou seja, causa menos repercussão no âmbito externo à relação de trabalho, a dispensa coletiva $^{52}$ destaca-se com uma maior gravidade, pois têm forte impacto social, expandido seus efeitos para uma comunidade mais ampla de onde se localiza a empresa ou estabelecimento ${ }^{53}$.

Destacando os graves efeitos característicos da prática da dispensa coletiva,

diz Delgado:

A dispensa coletiva configura, sem dúvida, frontal agressão aos princípios e regras constitucionais valorizadores do trabalho, do bem-estar, da segurança e da justiça social na vida socioeconômica, além dos princípios e regras constitucionais que subordinam o exercício da livre iniciativa e da propriedade privada à sua função social ${ }^{54}$.

No entanto, não é em todo e qualquer caso de dispensa coletiva que se observa a violação aos princípios e regras constitucionais mencionado por Delgado. É preciso, antes de se afirmar a ofensa, a análise das particularidades de casa caso, atentando se houve realmente um abuso do poder diretivo do empregador ao realizar as dispensas, se não houve tentativa prévia e espontânea de negociação coletiva, com a devida participação do sindicato profissional, e se poderiam ser adotadas medidas alternativas menos gravosas. Mesmo diante

\footnotetext{
${ }^{52} \mathrm{~A}$ dispensa plúrima, embora também se configure como uma resilição de uma pluralidade de contratos, não se assemelha aos efeitos da dispensa coletiva, uma vez que os trabalhadores dispensados serão substituídos, realizando-se, dessa forma, apenas a manutenção do quadro de desemprego já existente na sociedade. Além disso, por esta dispensa plúrima não se realizar diante de um motivo único, torna-se muito difícil a tarefa de sua limitação.

${ }^{53}$ Dentre os referidos graves efeitos sociais causados pela prática da dispensa coletiva, pode-se destacar o problema do desemprego. A dispensa de mais de 4 mil trabalhadores, realizada apenas pela Embraer, afeta sensivelmente toda a comunidade em que inserem estes trabalhadores - e também toda a sociedade - ao contribuir com o aumento do índice de desemprego na região. Além disso, o aumento do desemprego pode acarretar também o aumento ou intensificação de outras mazelas sociais, como a miséria, fome e violência.

${ }^{54}$ DELGADO, Maurício Godinho. Curso de direito do trabalho, p. 1155.
} 
dos graves efeitos sociais oriundos da prática da dispensa coletiva, somente a partir da observação específica de cada situação pode se concluir quais normas constitucionais e trabalhistas foram ou não ofendidas naquele contexto.

Em casos de dispensa coletiva, contudo, há de se ter a preocupação com a observância de alguns princípios e regras constitucionais importantes, que podem vir a ser suscitados ou discutidos diante do contexto do caso. Por exemplo, as normas constitucionais que determinam como fundamento do Estado Democrático de Direito os valores sociais do trabalho e da livre iniciativa (art. $1^{\circ}$, inciso IV) e os objetivos fundamentais da República brasileira (art. $3^{\circ}$ ) de construir uma sociedade livre, justa e solidária (inciso I), erradicar a pobreza e a marginalização e reduzir as desigualdades sociais e regionais (inciso III) e promover o bem de todos (inciso IV).

Outra importante norma a ser observada frente a casos de dispensa coletiva é a do art. $7^{\circ}$, inciso I, da Constituição Federal, que estabelece como direito do trabalhador a relação de emprego protegida contra despedida arbitrária ou sem justa causa, ainda que não haja, até hoje, lei complementar para regular tal situação ${ }^{55}$.

O forte impacto social gerado pela prática da dispensa coletiva atribui maior visibilidade a essa questão, e também maior preocupação, visto que seus efeitos se manifestam não somente sobre os trabalhadores dispensados, mas também sobre toda a comunidade. Apenas no caso Embraer, mais de quatro mil empregados foram alvo da dispensa coletiva realizada pela empresa. Se demais empresas nacionais, no mesmo contexto

\footnotetext{
${ }^{55}$ Podemos citar nesse elenco também as normas constitucionais do art. 193, que afirma que a ordem social tem como base o primado do trabalho, e como objetivo o bem-estar e a justiça sociais, e do art. 170 caput e incisos III, VII e VIII, que determinam que a ordem econômica deva sempre se fundar na valorização do trabalho humano e na livre iniciativa, buscando assegurar a todos existência digna, observando princípios como o da função social da propriedade, redução das desigualdades regionais e sociais e busca do pleno emprego. Além disso, deve se observar o disposto no Preâmbulo Constitucional, que determina como uma das metas do Estado Democrático brasileiro o exercício dos direitos sociais e individuais.
} 
da crise econômica mundial, praticassem a mesma medida, a situação, do ponto de vista social, seria ainda mais alarmante.

Nesse sentido, diante da repercussão social e econômica que provoca, Luiz Carlos Amorim Robortella destaca que a realização da dispensa coletiva deve estar sempre submetida a um controle estatal e sindical ${ }^{56}$. Assim, afirma o autor:

O Estado ou o sindicato devem ser informados previamente da medida empresarial, para que, dentro de um interregno razoável, soluções alternativas ${ }^{57}$ mereçam exame, com vistas à reconsideração da medida, readaptação profissional dos empregados envolvidos ou atenuação do impacto social. No caso de se recusar o empregador a cumprir tal procedimento, a lei deve impor uma indenização especial ${ }^{58}$.

\title{
3.3. Necessidade de regulamentação
}

\author{
Como afirma Delgado:
}

No Brasil, hoje, curiosamente, a lei não se contenta em considerar como ato afirmativo da individualidade do empregador a ruptura unilateral dos contratos de trabalho; até mesmo a dispensa maciça, coletiva, causadora de graves lesões sociais, é descurada pelo Direito do Trabalho no país ${ }^{59}$.

Na visão de determinados autores, a ausência de regulamentação específica

sobre a dispensa coletiva figura como a razão principal das controvérsias judiciais em relação

a casos dessa natureza, como observado no caso Embraer. Editar uma regulamentação nesse

\footnotetext{
${ }^{56}$ No mesmo entender, Nelson Mannrich afirma: “[...] deverá a dispensa coletiva submeter-se a duplo controle social: dos trabalhadores, por meio de seus representantes, que apresentarão soluções alternativas, com o fim de evitar a própria dispensa ou, na impossibilidade de evitá-la, minorar seus efeitos ${ }^{56}$; do Estado, exercendo controle de cunho formal, assegurando a regularidade do procedimento e estimulando a negociação, especialmente por meio da mediação." (ROBORTELLA, Luiz Carlos Amorim. Idéias para a reforma da legislação do trabalho. Revista do Advogado. São Paulo: Junho, ano XXV, n. 82, pg. 85-95, 2005, p. 91-92).

${ }^{57}$ Exemplos de tais soluções alternativas seria a redução da jornada de trabalho, redução salarial ou até mesmo a restrição temporária de outros direitos dos empregados, como férias e $13^{\circ}$ salário. Tais medidas poderiam ser adotadas, de forma temporária, desde que houvesse a contrapartida da garantia do emprego para os trabalhadores.

${ }^{58}$ ROBORTELLA, Luiz Carlos Amorim. Idéias para a reforma da legislação do trabalho. Revista do Advogado, p. 91.

${ }^{59}$ DELGADO, Maurício Godinho. Curso de direito do trabalho, p. 1155.
} 
sentido, no entanto, não se mostra uma tarefa simples. Como observa Gonçalves Júnior ${ }^{60}$, citando Orlando Gomes, a dificuldade em implementar uma regulamentação acerca da dispensa coletiva reside no fato de que o assunto exige tríplice enfoque ${ }^{61}$, pois tal regulamentação deve levar em conta os interesses da empresa, dos trabalhadores e também da sociedade.

Nesse sentido, explica Robortella que "a atual estrutura do mercado de trabalho é mesmo incompatível com uma rígida garantia de emprego ${ }^{62 \%}$. Além disso, a proibição rígida a toda espécie de dispensa coletiva não respeitaria a exigência de tríplice enfoque proposta por Orlando Gomes, pois não ponderaria o interesse das empresas e do mercado.

Observa-se ainda que não teria sentido forçar determinada empresa à falência por não poder praticar a dispensa coletiva, o que geraria um número ainda maior de desempregados e um impacto social ainda mais grave.

Dessa forma, para Gonçalves Júnior, com a combinação de dois fatores é possível estabelecer um critério satisfatório para determinar qual espécie de dispensa coletiva deve ser tutelada. Tais fatores seriam a "causa comum e impessoal que conduza à extinção de postos de trabalho definitivamente, e quantidade mínima de demissões simultâneas para que

\footnotetext{
${ }^{60}$ Segundo esse autor, há a necessidade, não só frente à questão da dispensa coletiva, de se remodelar ou reformar todo o Direito do Trabalho, no sentido de este se apresentar mais atualizado e melhor preparado para enfrentar os desafios impostos pela globalização. Um dos pontos que destacam essa necessidade é o descompasso entre o direito processual e o direito material do trabalho, uma vez que se têm diversos instrumentos adequados para a tutela coletiva de interesses, enquanto que o direito material ainda se apresenta "essencialmente individualista e ortodoxo". Dessa forma, "temos os instrumentos para aplicar a tutela coletiva, mas não temos direitos coletivos à altura para serem manejados por esses instrumentos". (GONÇALVES JÚNIOR, Mário. Demissão coletiva. Revista do direito trabalhista, p. 11)

${ }^{61}$ GONÇALVES JÚNIOR, Mário. Demissão coletiva. Revista do direito trabalhista, p. 10.

${ }^{62}$ ROBORTELLA, Luiz Carlos Amorim. Idéias para a reforma da legislação do trabalho. Revista do Advogado, p. 91.
} 
possam ser elegíveis medidas protecionistas adicionais criadas pela lei de demissão em $\operatorname{massa}^{63} \%$

Os principais mecanismos de proteção contra a dispensa coletiva oferecidos por uma regulamentação devem também ser mecanismos coletivos, no sentido de se adequarem mais a questão e terem a capacidade de oferecer melhor resposta. Exemplos de tais mecanismos seriam: a obrigação de comunicar o Estado e o sindicato acerca da intenção de realizar a dispensa coletiva, obrigação de negociação prévia da medida com o sindicato dos trabalhadores, obrigação de custear a recolocação de um percentual mínimo de dispensados no mercado de trabalho, preferência na admissão dos trabalhadores dispensados no caso da abertura de novas vagas, dentre demais medidas.

Destacando a necessidade de regulamentação da dispensa coletiva diante da gravidade dos efeitos provocados por esta medida, afirma Mannrich ${ }^{64}$ :

\begin{abstract}
A implantação do regime da dispensa coletiva se faz necessária em função das transformações do mercado de trabalho, determinadas pelas inovações tecnológicas, globalização da economia e avanço do setor terciário. A crise econômica, e o desemprego daí resultante, impuseram novas dimensões à dispensa coletiva: seus efeitos ultrapassaram os limites dos sujeitos contratuais, para atingir a toda sociedade ${ }^{65}$.
\end{abstract}

Conforme evidenciado, determinados autores, como Delgado e Mannrich, defendem a necessidade de se criar uma regulamentação para tratar de casos de dispensa coletiva, acreditando que com a edição de regras jurídicas específicas a questão receberá um tratamento mais adequado, expondo claramente as condições diante das quais as dispensas

${ }^{63}$ GONÇALVES JÚNIOR, Mário. Demissão coletiva. Revista do direito trabalhista, p. 12.

${ }^{64}$ Salomão também afirma a importância de se buscar tal regulamentação, uma vez que "é extremamente importante visto que a dispensa, em todas as suas formas e principalmente na forma de dispensa coletiva gera problemas de cunho social, em função das transformações do mercado de trabalho determinadas pelas inovações tecnológicas e pela globalização, deixando de afetar apenas o empregado atingido pela perda do emprego e ganhando contornos de problema social". (SALOMÃO, Claudia Regina. A dispensa coletiva no ordenamento jurídico brasileiro e a influência da Convenção n. 158 da OIT. Legislação do Trabalho, p. 450).

${ }^{65}$ ROBORTELLA, Luiz Carlos Amorim. Idéias para a reforma da legislação do trabalho. Revista do Advogado, p. 92. 
poderão ser realizadas, e assim evitando os abusos por parte do empregador e trazendo maior proteção e segurança jurídica ao trabalhador.

Contudo, a omissão legislativa quanto ao tema não pode levar ao entendimento de que o ordenamento jurídico nacional buscou permitir a realização da dispensa coletiva sem a observância de qualquer tipo de limites ou restrições. Tais limites, conforme será analisado mais adiante, podem ser visualizados a partir de uma leitura principiológica do texto constitucional e também diante da efetiva atuação sindical, de forma que, independentemente de lei posterior que venha a regular expressamente a dispensa coletiva, limitações a essa prática já se fazem presentes na ordem constitucional.

Além disso, não se pode afirmar que a regulamentação da dispensa coletiva venha a contribuir para a redução dos abusos e excessos do poder diretivo do empregador. Como bem destaca Guilherme Scotti Rodrigues:

[...] é de se lembrar que abusos e pretensões a direitos existirão independentemente de regulação legislativa, não podendo jamais ser definitivamente coibidos em abstrato. Aliás, é precisamente a regulação legislativa abstrata que por só há que ser vista como incentivadora de abusos. Apenas num discurso de aplicação que leve a sério as especificidades de cada caso concreto as ilegítimas pretensões a direitos, calcadas inclusive em previsões legais literais, poderão ser desveladas como abusos, como não direito $^{66}$.

Conforme expõe Menelick de Carvalho Netto, a idéia da regulamentação como resposta mais adequada à problemática da dispensa coletiva "revela a crença de que

${ }^{66}$ RODRIGUES, Guilherme Scotti. A afirmação da justiça como a tese da única decisão correta: o enfrentamento da questão do caráter estruturalmente indeterminado do direito moderno. 2008. Dissertação (Mestrado em "Direito, Estado e Constituição). Faculdade de Direito, Universidade de Brasília, Brasília, p. 88. 
todos os problemas e virtudes de nossa vida jurídica dependeriam da qualidade literal de nossos textos legislativos ${ }^{67,}$. Diante disso, explica o autor:

Esquece-se que os textos são o objeto da atividade de interpretação e não o seu sujeito; que o anseado aprimoramento de nossas instituições pode requerer algo muito mais complexo do que a simples reforma de textos constitucionais e legislativos. Tudo está a indicar que a reforma, para ser produtiva, deveria dar-se precisamente no âmbito das posturas e das práticas sociais, ou seja, das gramáticas mediante as quais implementamos nossa vida $\operatorname{cotidiana}^{68}$.

Não se pode concluir, dessa forma, que a regulamentação específica da dispensa coletiva possa vir a solucionar as controvérsias judiciais existentes em casos dessa natureza, uma vez que não se pode encorajar “à crença irracional de que textos racionalmente elaborados poderiam reduzir a complexidade da tarefa interpretativa ${ }^{69 "}$ realizada pelo aplicador do direito.

\subsection{A dispensa coletiva no direito internacional: a Convenção n. 158 da OIT}

Diferentemente da realidade infraconstitucional interna brasileira, onde, conforme já exposto, há uma verdadeira omissão legislativa em relação ao tratamento da dispensa coletiva de trabalhadores, no plano do direito internacional essa prática encontra importante regulação pela Convenção n ${ }^{\circ} .158$ da Organização Internacional do Trabalho ${ }^{70}$.

${ }^{67}$ CARVALHO NETTO, Menelick de. A hermenêutica constitucional sob o paradigma do Estado Democrático de Direito. Revista Notícia do Direito Brasileiro, Brasília, jul./dez, v. 6, 1998, p 235.

${ }^{68}$ CARVALHO NETTO, Menelick de. A hermenêutica constitucional sob o paradigma do Estado Democrático de Direito. Revista Notícia do Direito Brasileiro, p. 235.

69 RODRIGUES, Guilherme Scotti. A afirmação da justiça como a tese da única decisão correta: o enfrentamento da questão do caráter estruturalmente indeterminado do direito moderno, p. 10.

${ }^{70}$ Ressalta-se que mesmo antes da Convenção n. 158 ser promulgada já havia, no plano internacional, a preocupação com a necessidade de regulamentação da dispensa coletiva. Isso se reflete na Recomendação $\mathrm{n}$. 119 de 26 de junho de 1963, adotada pela Conferência Internacional do Trabalho, cujo objetivo era o de estabelecer regras de conduta, destinadas a atenuar o impacto social, referentes ao término da relação de trabalho. Porém, a Recomendação apenas sugere medidas, uma vez que, diferentemente da Convenção, esta não tem cunho obrigacional, agindo mais como um parâmetro de condutas, pois não impõe qualquer tipo de sanção ao seu descumprimento. (SOUTO MAIOR, Jorge Luiz. Convenção 158 da OIT. Dispositivo que 
A referida Convenção, promulgada em 1982 com o intuito de se estabelecer regras sobre a dispensa individual e coletiva, foi aprovada pelo Congresso Nacional brasileiro em 16 de setembro de 1992, através do Decreto Legislativo $n^{\circ}$. 68, tendo sido a carta de ratificação depositada na RIT $^{71}$ (Repartição Internacional do Trabalho, da OIT) em 05 de janeiro de 1995 e os termos da Convenção tornados públicos em território nacional mediante o Decreto $\mathrm{n}^{\circ} .1 .855$ de 11 de abril de 1996.

No entanto, diante do entendimento predominante à época da inaplicabilidade da Convenção no ordenamento jurídico nacional, como afirma Souto Maior, a Convenção n.158 da OIT foi denunciada pelo Poder Executivo através do Decreto n. 2.100, de 20 de dezembro de $1996^{72}$, publicado em 23 de dezembro do mesmo ano, restando vigência para a referida Convenção até 20 de novembro de 1997.

Essa denúncia, aponta Túlio Viana, seria inconstitucional, uma vez que o chefe do Poder Executivo estaria extrapolando os limites de sua competência, determinada pelo art. 84 da Constituição Federal, ao denunciar, por Decreto, e assim por ato isolado, a Convenção que necessitou de aprovação do Congresso Nacional para ter vigência em território nacional.

\footnotetext{
veda a dispensa arbitrária é $\quad$ auto-aplicável. $\quad$ Disponível $\quad$ em <http://jus2.uol.com.br/doutrina/texto.asp?id=5820> Acesso em: 15 de junho, 2009).

${ }^{71}$ Procedimento necessário para a entrada em vigor no Estado-membro da Convenção ratificada, o que ocorre doze meses após esse depósito no RIT. No caso do Brasil, dessa forma, a Convenção n ${ }^{\circ} .158$ passou a ter vigência em território nacional a partir de 6 de janeiro de 1996, sendo que a exigência de publicação no âmbito interno só foi cumprida com o Decreto $\mathrm{n}^{\circ} .1 .855$, em 11 de abril do mesmo ano.

${ }^{72}$ Salomão afirma que na época em que ocorreu a denúncia da Convenção n. 158 da OIT, o Governo brasileiro, buscando minimizar o impacto desta, apresentou um anteprojeto de lei complementar que tinha como objetivo regular o disposto no art. 7, inciso I, da Constituição Federal. Tal anteprojeto previa, em seu art. 6, § 1, diversas medidas a serem aplicáveis diante de casos de dispensa coletiva. (SALOMÃO, Claudia Regina. A dispensa coletiva no ordenamento jurídico brasileiro e a influência da Convenção n. 158 da OIT. Legislação do Trabalho, p. 453-454).
} 
Para Souto Maior, no mesmo entender de Viana, a citada denúncia se apresenta como ato inconstitucional ${ }^{73}$, e, portanto, não teria o condão de extrair a Convenção n. 158 da OIT do ordenamento jurídico nacional, restando essa ainda válida e plenamente aplicável. Segundo o autor, não procede também a alegação de os termos da Convenção seriam inaplicáveis dentro da ordem jurídica brasileira por incompatibilidade com as normas e preceitos constitucionais $^{74}$, pois a Convenção atua no mesmo sentido do já determinado pela Constituição no art. 7, inciso I, ou seja, buscar vedar a dispensa arbitrária ${ }^{75}$.

\section{Afirma Souto Maior:}

Assim, a Convenção, estando de acordo com o preceito constitucional estatuído no artigo $7^{\circ}$, inciso I, complementa-o, não havendo qualquer validade no argumento de ausência de lei complementar, em razão de seu quorum qualificado, nega a aplicabilidade da Convenção, até porque a formação de uma Convenção, que se dá no âmbito internacional, exige muito mais formalismos que uma lei complementar, sendo fruto de um profundo amadurecimento internacional quando à matérias por ela tratadas ${ }^{76}$.

Assim, embora a referida norma constitucional tenha resguardado a

regulação da questão para lei complementar, não haveria incompatibilidade em relação à

\footnotetext{
${ }^{73}$ Como aponta Souto Maior, "todo o Decreto do Presidente da República, inicia-se com os termos "O Presidente da República no uso da atribuição que lhe confere o inciso IV, do art. 84 da Constituição Federal" ou "no uso da atribuição que lhe confere o inciso VI, (alínea "a" ou "b") do art. 84 da Constituição Federal", decreta...Mas, no caso do Decreto 2.100/96, apenas se disse de forma um tanto quanto marota que O PRESIDENTE DA REPÚBLICA, tornava público que "deixará de vigorar para o Brasil, a partir de 20 de novembro de 1997, a Convenção da OIT no 158, relativa ao Término da Relação de Trabalho por Iniciativa do Empregador, adotada em Genebra, em 22 de junho de 1982, visto haver sido denunciada por Nota do Governo brasileiro à Organização Internacional do Trabalho, tendo sido a denúncia registrada, por esta última, a 20 de novembro de 1996". (SOUTO MAIOR, Jorge Luiz. Convenção 158 da OIT. Dispositivo que veda a dispensa arbitrária é auto-aplicável. Disponível em 〈http://jus2.uol.com.br/doutrina/texto.asp?id=5820> Acesso em: 15 de junho, 2009).

${ }^{74}$ Além disso, a idéia de que as normas dispostas pela Convenção n. 158 da OIT necessitariam, no plano interno ou nacional, de demais normas reguladoras, uma vez que não seriam auto-aplicáveis, também não se apresenta correta. Observa-se que apenas a "Parte I" dessa Convenção teria um caráter conceitual, sendo o restante já de cunho normativo, adotando, inclusive, uma técnica gramatical de interpretação, "que embora não seja autosuficiente, dela não se pode fugir, não se extrai qualquer dúvida de conteúdo". (SOUTO MAIOR, Jorge Luiz. Convenção 158 da OIT. Dispositivo que veda a dispensa arbitrária é auto-aplicável. Disponível em <http://jus2.uol.com.br/doutrina/texto.asp?id=5820> Acesso em: 15 de junho, 2009).

${ }^{75}$ A ausência de lei complementar que regule o exposto no art. 7, inciso I, da Constituição Federal, não impede a eficácia deste preceito, ou seja, ele se põe desde já válido e plenamente eficaz, no sentido de que futura lei complementar apenas traria uma melhor e mais detalhada regulação acerca da questão.

${ }^{76}$ SOUTO MAIOR, Jorge Luiz. Convenção 158 da OIT. Dispositivo que veda a dispensa arbitrária é autoaplicável. Disponível em <http://jus2.uol.com.br/doutrina/texto.asp?id=5820> Acesso em: 15 de junho, 2009.
} 
Convenção da OIT trazer dispositivos de enfrentamento desse problema, pois esta se sujeita à um maior formalismo para sua formação e ratificação pelos Estados-membros, e também devido ao fato dessa lei complementar "após transcorridos longos anos, ainda não foi concluída, e, sobretudo, quando a lacuna deixada provoca, em concreto, a ineficácia de preceitos constitucionais consagrados como garantias fundamentais ${ }^{77}$,"

Essa controversa questão acerca da compatibilidade da Convenção n. 158 no ordenamento jurídico nacional e da inconstitucionalidade da denúncia encontra-se, ainda hoje, na pauta do Supremo Tribunal Federal através da ADI/1625, proposta pela Confederação Nacional dos Trabalhadores na Agricultura (CONTAG) ainda em 1997. Sobre esta, manifestaram-se já os Senhores Ministros Maurício Corrêa, relator do processo, e Carlos Britto, ambos julgando procedente, em parte, a ação ${ }^{78}$ :

[...] EMPRESTANDO AO DECRETO FEDERAL $N^{o}$ 2.100, DE 20 DE DEZEMBRO DE 1996, INTERPRETAÇÃO CONFORME O ARTIGO 49, INCISO I DA CONSTITUIÇÃO FEDERAL, DETERMINAR QUE A DENÚNCIA DA CONVENÇÃO 158 DA OIT CONDICIONA-SE AO REFERENDO DO CONGRESSO NACIONAL, A PARTIR DO QUE PRODUZ A SUA EFICÁCIA ${ }^{79}$.

Como afirma Salomão, com essa denúncia verificou-se a real ausência de qualquer instrumento legislativo no ordenamento nacional ${ }^{80}$ que visasse a regulação

\footnotetext{
${ }^{77}$ SOUTO MAIOR, Jorge Luiz. Convenção 158 da OIT. Dispositivo que veda a dispensa arbitrária é autoaplicável. Disponível em <http://jus2.uol.com.br/doutrina/texto.asp?id=5820> Acesso em: 15 de junho, 2009.

${ }^{78}$ Em sentido oposto, o Ministro NELSON JOBIM, julgou improcedente a ação. Já o Ministro JOAQUIM BARBOSA julgou totalmente procedente a ação.

${ }^{79}$ SUPREMO TRIBUNAL FEDERAL. ADI-1625. Relator: Ministro Maurício Corrêa. Decisão publicada no DJ Nr. 80 do dia 27/04/2006.

${ }^{80}$ A autora aponta que, ainda que não haja no Brasil qualquer tipo de regulação específica sobre a dispensa coletiva, houve tentativas, notadamente por parte do Ministério do Trabalho, de se estabelecer determinados procedimentos referentes à casos concretos em que se observasse tal prática. Tais tentativas se refletem pela Portaria n. 3.218, de 09 de julho de 1987 e também pela Portaria n. 01, de 9 de janeiro de 1992. No entanto, da mesma forma que a Regulamentação da OIT, a portaria não prevê qualquer tipo de sanção em relação às empresas que descumprirem suas medidas, sendo vista apenas como uma orientação (SALOMÃO, Claudia Regina. A dispensa coletiva no ordenamento jurídico brasileiro e a influência da Convenção n. 158 da OIT. Legislação do Trabalho, p. 453-454).
} 
específica de casos de dispensa coletiva. Segundo a autora, tal Convenção era de grande importância no contexto interno brasileiro por que:

[...] foi com o advento da Convenção n. 158 da OIT no ordenamento jurídico brasileiro em 1996 que foi atendida à dupla finalidade: por um lado protegeu o trabalhador contra a dispensa arbitrária e por outro, preservou o direito do empregador de pôr fim ao contrato na ocorrência de causa justificada ${ }^{81}$.

A partir de uma análise mais específica dos artigos 13 e $14^{82}$ dessa Convenção - que nasceu com base no princípio fundamental de proteção contra dispensa arbitrária, exposto igualmente na Constituição Federal brasileira - observa-se que a esta reconheceu a importância da atuação dos sindicatos - ou representantes dos trabalhadores - e do Estado nos casos de dispensa coletiva como limitadores ou atenuantes dessa prática.

A análise desse diploma jurídico internacional demonstra a preocupação mundial quanto à questão da dispensa coletiva ${ }^{83}$. Ainda que denunciada pelo Poder Executivo nacional, a Convenção n. 158 pode figurar como um horizonte para a prática judicial brasileira, inspirando o aplicador do direito a buscar uma conciliação harmônica entre os interesses do empregador, dos trabalhadores e da sociedade.

81 SALOMÃO, Claudia Regina. A dispensa coletiva no ordenamento jurídico brasileiro e a influência da Convenção n. 158 da OIT. Legislação do Trabalho, p. 450.

${ }^{82}$ No art. 13, tem-se que: Artigo 13: "1. Quando o empregador prever términos da relação de trabalho por motivos econômicos, tecnológicos, estruturais ou análogos; a) Proporcionará aos representantes dos trabalhadores interessados, em tempo oportuno, a informação pertinente [...] b) em conformidade com a legislação e a prática nacionais, oferecerá aos representantes dos trabalhadores interessados, o mais breve que for possível, uma oportunidade para realizarem consultas sobre as medidas que deverão ser adotadas para evitar ou limitar os términos e as medidas para atenuar as conseqüências adversas" No art. 14, prevê também que quando da realização dos términos "deverá notificá-los o mais breve possível à autoridade competente". (OIT, Convenção n. 158 (1985). Disponível em < http://s.conjur.com.br/dl/convencao-oit-158.pdf $>$ Acesso em: 17 de junho, 2009).

83 Também a Convenção Americana de Direitos Humanos - o chamado Pacto de San José da Costa Rica-, adotada em 1969 e ratificada pelo Brasil em 25 de setembro de 1992, traz em seu Protocolo Adicional "Protocolo de San Salvador" - importante norma internacional contra a prática da dispensa arbitrária ou sem justa causa. Assim, o artigo 7, d, do referido Protocolo Adicional estabelece: "d. Estabilidade dos trabalhadores em seus empregos, de acordo com as características das indústrias e profissões e com as causas de justa separação. Nos casos de demissão injustificada, o trabalhador terá direito a uma indenização ou à readmissão no emprego ou a quaisquer outras prestações previstas pela legislação nacional;”. 
Independentemente do questionamento sobre a aplicabilidade da Convenção n. 158 no país, cabe observar que existe no ordenamento constitucional nacional normas que indicam limitações à realização de dispensa coletiva. A fim de identificar tais normas e a fundamentação de sua aplicação e eficácia, torna-se necessária uma importante leitura principiológica do ordenamento constitucional, buscando evidenciar os abusos cometidos pela empresa no exercício de seu poder de comando e destacar que a falta de lei específica sobre a dispensa coletiva não implica em afirmar que estamos diante de uma ausência de qualquer tipo de controle a essa prática. 


\section{CAMINHOS PARA A CONSTRUÇÃO DE LIMITES À DISPENSA COLETIVA}

A dispensa coletiva de trabalhadores realizada pela Embraer no início do presente ano reflete a gravidade do quadro atual de crise econômica mundial e a repercussão de seus efeitos também políticos, jurídicos e sociais, inclusive no Brasil, tido como pouco afetado pelo problema.

É evidente os efeitos da crise sobre o setor de aviação, não só no país como no restante do mundo. Com a expectativa de pouco crescimento econômico para 2009, a tendência é a redução das exportações e do comércio internacional, realidade essa que afeta drasticamente empresas como a Embraer, que tem no mercado externo a principal fonte de renda.

Dessa forma, reconhecendo que a indústria de aviação enfrenta uma grave crise, medidas como a dispensa coletiva de empregados podem se apresentar como respostas últimas para a sobrevivência da empresa ${ }^{84}$ diante desse quadro ${ }^{85}$. No entanto, tal medida, por gerar graves efeitos sociais, não pode ser realizada sem qualquer tipo de limitação ou controle, entendendo-se apenas que a empresa exercita seu direito de legitimamente denunciar contratos de trabalho.

É certo que a crise econômica deve ser um fator relevante a pesar na análise do caso, porém não pode esta representar uma "carta branca" para a inobservância dos direitos

\footnotetext{
${ }^{84}$ Deve-se observar, conforme dispõe o art. $2^{\circ}$, caput, da CLT, que quem assume os riscos da atividade econômica é o empregador, e não os empregados. Dessa forma, e dispensa coletiva só seria "aceitável" se tida como a última medida possível para evitar a falência da empresa, o que aumentaria ainda mais o número de dispensados.

${ }^{85}$ Uma vez que, diante de intenso diálogo com o sindicato profissional, qualquer outra medida alternativa à dispensa coletiva se mostrasse infrutífera para socorrer a empresa, não haveria sentido em se proibir terminantemente a realização das dispensas, visto que se a empresa for obrigada a "fechar suas portas", encerrando suas atividades, o impacto sócio-econômico seria muito mais grave, pois a massa de trabalhadores desempregados seria ainda maior.
} 
fundamentais e sociais relativos aos trabalhadores expostos pela Constituição Federal, como a dignidade da pessoa humana, a valorização do trabalho e a proteção contra dispensa arbitrária.

Nesse sentido, busca-se o entendimento de que a prática da dispensa coletiva deve estar sempre condicionada a um controle por parte do Estado, através de suas atividades legislativa e jurisdicional, e também um controle por parte dos sindicatos, como visto nas repercussões da atuação coletiva sobre o poder diretivo.

Cabe analisar primeiramente de que forma, diante da visão exposta no presente estudo, deve se fundamentar a atuação jurisdicional do Estado no sentido de realizar uma construção interpretativa que permita estabelecer limites à dispensa coletiva.

\subsection{A postura do juiz dentro do paradigma do Estado Democrático de Direito}

A omissão do legislador quanto à dispensa coletiva gera grandes divergências e controvérsias entre juízes e tribunais acerca da melhor resposta ou da solução mais adequada para o caso, uma vez que, conforme mencionou o próprio relator do processo no TRT da $15^{\text {a }}$ Região, José Antonio Pancotti, a falta de legislação foi um dos empecilhos que levou às controvérsias na decisão desde a primeira audiência de conciliação.

Porém, a falta de regulamentação específica sobre o tema ou a inexistência de vedação expressa à sua prática não pode ser compreendida como um permissivo legal, ou seja, que a dispensa coletiva pode ser efetuada pelo empregador sem a observância de qualquer tipo de limitação ou restrição. 
Como bem observa Menelick, essa idéia reflete ainda uma concepção característica do paradigma do Estado de Direito, que consagra os direitos individuais - ou chamados direitos de primeira geração - e afirmam que "liberdade é fazer tudo aquilo que as leis não proíbam ${ }^{86,}$, limitando a atuação estatal à legalidade, ao mesmo tempo em que delimita o espaço de atuação dos indivíduos. No entanto, esse pensamento foi superado já com a posterior concepção dominante dentro do Estado Social, ou Estado de Bem-Estar Social $^{87}$.

Segundo Menelick, a Constituição Federal de 1988 positivou e inaugurou o novo paradigma do Estado Democrático de Direito, exigindo assim também uma nova postura do Judiciário $^{88}$, mais adequada às idéias concebidas dentro desse novo contexto jurídico. Como afirma o autor:

[...] no paradigma do Estado Democrático de Direito, é preciso requerer do Judiciário que tome decisões que, ao retrabalharem construtivamente os princípios e as regras constitutivos do direito vigente, satisfaçam, a um só tempo, a exigência de dar curso e reforçar a crença tanto na legalidade, entendida como segurança jurídica, como certeza do direito, quanto no sentimento de justiça realizada, que deflui da adequabilidade da decisão às particularidades do caso concreto ${ }^{89}$.

${ }^{86}$ CARVALHO NETTO, Menelick de. A hermenêutica constitucional sob o paradigma do Estado Democrático de Direito. Revista Notícia do Direito Brasileiro, p. 240.

87 Como expõe Menelick, em relação ao paradigma do Estado Social: "A liberdade não mais pode ser considerada como o direito de se fazer tudo o que não seja proibido por um mínimo de leis, mas agora pressupõe precisamente toda uma plêiade de leis sociais e coletivas que possibilitem, no mínimo, o reconhecimento das diferenças materiais e o tratamento privilegiado do lado social ou economicamente mais fraco da relação" (CARVALHO NETTO, Menelick de. A hermenêutica constitucional sob o paradigma do Estado Democrático de Direito. Revista Notícia do Direito Brasileiro, p. 242).

${ }^{88}$ Passa a se exigir uma "postura do juiz em uma tutela jurisdicional constitucionalmente adequada ao paradigma do Estado Democrático de Direito" (CARVALHO NETTO, Menelick de. A hermenêutica constitucional sob o paradigma do Estado Democrático de Direito. Revista Notícia do Direito Brasileiro, p. 236).

${ }^{89}$ CARVALHO NETTO, Menelick de. A hermenêutica constitucional sob o paradigma do Estado Democrático de Direito. Revista Notícia do Direito Brasileiro, p. 245. 
A compreensão do pensamento jurídico trazido por esse novo paradigma é importante uma vez que a atividade jurisdicional ${ }^{90}$ exerce "um papel central na arquitetura constitucional $^{91 ” .}$. Destaca Menelick:

Assim, acreditamos que o Judiciário ocupe um papel central na árdua tarefa de promover não somente a segurança jurídica, mas a crença no próprio direito, na justiça. Outra característica essencial do direito moderno é seu caráter textual, o fato de que só temos acesso às suas normas mediante textos discursivamente construídos e reconstruídos. Portanto, os supostos de atividade de interpretação de todos os operadores jurídicos, do legislador ao destinatário da norma, são da maior relevância para a implementação de um ordenamento $^{92}$.

\title{
3.5.1. Uma leitura principiológica: o Direito como integridade
}

\author{
Segundo Guilherme Scotti Rodrigues:
}

Dworkin defende que a postura a ser adotada pelo aplicador do direito deve ser a de buscar a única resposta correta no ordenamento jurídico em sua integridade, diante das especificidades de cada caso concreto, compreendendo os princípios jurídicos como normas deontológicas que estabelecem direitos e deveres que pré-existem ao momento da decisão, não estando, portanto, sujeito à discricionariedade do aplicador, muito menos à uma escolha entre valores concorrentes que implique no sacrifício de direitos, que não se confundem com interesses ${ }^{93}$.

A postura a que Dworkin se refere é a mesma defendida por Menelick, conforme exposto anteriormente, como a postura adequada ao novo paradigma do Estado Democrático de Direito $^{94}$. Diante dessa postura, exige-se que o juiz, ou aplicador do direito,

\footnotetext{
${ }^{90}$ No mesmo sentido, ressaltando a importância da função jurisdicional, afirma Dworkin: “A diferença entre dignidade e ruína pode depender de um simples argumento que talvez não fosse poderoso aos olhos de outro juiz, ou mesmo o mesmo juiz no dia seguinte. As pessoas freqüentemente se vêem na iminência de ganhar ou perder muito mais em decorrência de um aceno de cabeça do juiz do que qualquer norma geral que provenha do legislativo" (DWORKIN, Ronald. O império do direito. São Paulo: Martins Fontes, 1999, p. 03).

${ }^{91}$ CARVALHO NETTO, Menelick de. A hermenêutica constitucional sob o paradigma do Estado Democrático de Direito. Revista Notícia do Direito Brasileiro, p. 235.

${ }^{92}$ CARVALHO NETTO, Menelick de. A hermenêutica constitucional sob o paradigma do Estado Democrático de Direito. Revista Notícia do Direito Brasileiro, p. 235.

93 RODRIGUES, Guilherme Scotti. A afirmação da justiça como a tese da única decisão correta: o enfrentamento da questão do caráter estruturalmente indeterminado do direito moderno, p. 11.

${ }^{94}$ No entanto, conforme expõe Dworkin, não é todo e qualquer tipo de comunidade que acolhe essa postura e suas exigências de integridade. Para o autor, somente "numa comunidade de princípios as normas estabelecidas podem ganhar conteúdo universal e serem vistas como condição de possibilidade para a
} 
ao apreciar um caso concreto, considere sempre o ordenamento jurídico em sua integridade, sob o risco de gerar uma decisão injusta se não o fizer.

Entendendo-se, como afirma Dworkin, que a melhor ou mais correta - e assim, única possível - decisão judicial deve buscar garantir não somente a crença na legalidade ou segurança jurídica, mas também operar justiça no caso concreto, o presente estudo adota a concepção de direito como integridade.

Nessa visão, tem-se que:

Segundo o direito como integridade, as proposições jurídicas são verdadeiras se constam ou derivam, dos princípios de justiça, equidade e devido processo legal que oferecem a melhor interpretação construtiva da prática jurídica da comunidade $^{95}$.

Voltando a Rodrigues, este afirma que no pensamento característico do positivismo jurídico, “a noção de segurança jurídica se sobrepõe, abarca, eclipsa a idéia de justiça enquanto pretensão de correção normativa ${ }^{96, "}$. Assim, para os positivistas, o ordenamento jurídico é tido como um sistema fixo de regras que regulam todo o âmbito de conduta humana.

Porém, construir a idéia de um sistema fixo implica também em reconhecer que este poderá apresentar lacunas legais em relação a certos casos. Nesse sentido, a discricionariedade do juiz exerceria o importante papel de preencher tais lacunas, criando e de seus princípios". (DWORKIN, Ronald. O império do direito, p. 24).

${ }^{95}$ DWORKIN, Ronald. O império do direito, p. 272.

${ }^{96}$ RODRIGUES, Guilherme Scotti. A afirmação da justiça como a tese da única decisão correta: o enfrentamento da questão do caráter estruturalmente indeterminado do direito moderno, p. 15. 
aplicando retroativamente uma nova norma jurídica ${ }^{97}$, que decorreria de um direito préexistente, e buscando, assim, manter a ilusão da certeza jurídica ${ }^{98}$.

Diferentemente, para Dworkin, destaca Rodrigues:

[...] mesmo nesses casos considerados pelo positivismo como hard cases $^{99}$, onde não há uma regra estabelecida dispondo claramente sobre o caso, uma das partes pode mesmo assim ter um direito pré-estabelecido de ter sua pretensão assegurada. Cabe ao juiz descobrir quais são esses direitos, mas isso não poderá ser obtido com auxílio de algum método ou procedimento mecanicista. Dworkin deixa claro que se trata primeiramente de uma postura a ser adotada pelo aplicador diante da situação concreta e com base nos princípios jurídicos, entendidos em sua integridade ${ }^{100}$.

Entender os princípios jurídicos em sua integridade, conforme defende

Dworkin, pressupõe que:

Se as pessoas aceitam que são governadas não apenas por regras explícitas, estabelecidas por decisões políticas tomadas no passado, mas por quaisquer outras regras que decorrem dos princípios que essas decisões pressupõem, então o conjunto de normas públicas reconhecidas pode expandir-se e contrair-se organicamente, à medida que as pessoas se tornem mais sofisticadas em perceber e explorar aquilo que esses princípios exigem sob novas circunstâncias, sem a necessidade de um detalhamento da legislação ou da jurisprudência de cada um dos possíveis pontos de conflito ${ }^{101}$.

Essa visão, aduz Rodrigues, permite a existência de discordâncias e controvérsias entre juízes, tribunais, advogados e até cidadãos acerca de qual seria a correta

\footnotetext{
${ }^{97}$ Segundo Dworkin, "é errado sacrificar os direitos de um homem inocente em nome de algum novo dever, criado depois do fato; portanto parece errado tomar os bens de um individuo e dá-los a outro, apenas para melhorar a eficiência econômica global (DWORKIN, Ronald. O império do direito, p 133.)

${ }^{98}$ DWORKIN, Ronald. O império do direito, p. 16-18.

99 Esses hard cases, ou casos difíceis, conforme nomeou Dworkin, são casos "onde não há uma regra estabelecida dispondo claramente sobre o caso" (RODRIGUES, Guilherme Scotti. A afirmação da justiça como a tese da única decisão correta: o enfrentamento da questão do caráter estruturalmente indeterminado do direito moderno, pg. 18).

100 RODRIGUES, Guilherme Scotti. A afirmação da justiça como a tese da única decisão correta: o enfrentamento da questão do caráter estruturalmente indeterminado do direito moderno, p. 18.

${ }^{101}$ DWORKIN, Ronald. O império do direito, p. 229.
} 
decisão para determinado caso concreto, uma vez que estes podem possuir conceitos diferentes de direito ou de justiça ${ }^{102}$.

Para Dworkin, a postura do juiz diante de um caso difícil, numa concepção positivista, é a de atuar como um segundo legislador, no sentido em que cria novo direito diante da omissão legal característica desse caso. Porém, tal postura é inadequada por criar uma confusão entre os chamados argumentos de princípio e argumentos de política. Segundo o autor:

Os argumentos de política justificam uma decisão política, mostrando que a decisão fomenta ou protege algum objetivo coletivo da comunidade como um todo. (...) Os argumentos de princípio justificam uma decisão política, mostrando que a decisão respeita ou garante um direito de um indivíduo ou de um grupo ${ }^{103}$.

Tal confusão entre esses argumentos se faz presente no positivismo jurídico

da seguinte forma:

Se os juízes atuam como legisladores delegados, como na concepção positivista, então toda gama de argumentos de política está à sua disposição. Um caso pode ser decidido, na ausência de uma regra, de forma a promover, por exemplo, a maximização de objetivos econômicos considerados relevantes pelo juiz, ou a prevalência de valores sociais considerados superiores ${ }^{104}$, sem que isso reflita necessariamente princípios jurídicos enquanto comandos normativos deontológicos. Se, por outro lado, a tarefa jurisdicional se distingue em essência da atividade legislativa, atuando como um fórum de princípio, nos hard cases as decisões devem se basear em

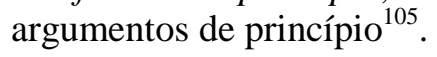

Nesse entender, destaca Menelick que:

102 RODRIGUES, Guilherme Scotti. A afirmação da justiça como tese da única decisão correta: o enfrentamento da questão do caráter estruturalmente indeterminado do direito moderno, p. 19.

${ }^{103}$ DWORKIN, Ronald. Levando os direitos a sério. São Paulo: Martins Fontes, 2002, p. 129.

${ }^{104}$ Para Dworkin: "No caso dos princípios, contudo, a doutrina insiste na aplicação da consistência distributiva a todos os casos, pois não admite a idéia de uma estratégia que possa ser mais bem servida pela distribuição desigual do benefício em questão". (DWORKIN, Ronald. Levando os direitos a sério. São Paulo: Martins Fontes, 2002, p. 138).

105 RODRIGUES, Guilherme Scotti. A afirmação da justiça como a tese da única decisão correta: o enfrentamento da questão do caráter estruturalmente indeterminado do direito moderno, p. 20. 
[...] o aplicador deve exigir então que o ordenamento jurídico se apresente diante dele não por meio de uma única regra integrante de um todo passivo, harmônico e predeterminado que já teria de antemão regulado de modo absoluto a aplicação de suas regras, mas em sua integralidade, como um mar revolto de normas em permanente tensão concorrendo entre si para regerem situações ${ }^{106}$.

A crítica em relação às decisões dos tribunais acerca do caso Embraer se realiza exatamente no sentido da postura adotada por estes em relação ao caso, revelando que tais decisões não refletiram a melhor interpretação construtiva da prática jurídica da comunidade, pois não garantiram, a um só tempo, a segurança jurídica e a crença na justiça, de acordo com as particularidades do caso ${ }^{107}$.

Ao ver desse estudo, a decisão do Ministro Presidente do TST diante de um hard case - a dispensa coletiva - adotou argumentos de política relacionados à crise econômica mundial, privilegiando normas garantidoras do poder diretivo do empregador, e assim não realizando um efetivo fórum de princípios, como defendia Dworkin.

Concluindo assim, Menelick afirma, citando Dworkin:

Não levar a sério os direitos, ou seja, simplificar uma situação de aplicação de modo a simplesmente desconhecer direitos dos envolvidos por se enfocar a questão do ângulo de um único princípio aplicado ao modo do tudo ou nada, típico das regras, termina por subverter o próprio valor da segurança jurídica que se pretendera assegurar ${ }^{108}$.

\footnotetext{
${ }^{106}$ CARVALHO NETTO, Menelick de. A hermenêutica constitucional sob o paradigma do Estado Democrático de Direito. Revista Notícia do Direito Brasileiro, p. 246.

${ }^{107}$ Como destaca Dworkin, deve- buscar evitar "a prática de tomar decisões que pareçam certas isoladamente, mas que não podem fazer parte de uma teoria abrangente dos princípios e das políticas gerais que seja compatível com outras decisões igualmente consideradas". (DWORKIN, Ronald. Levando os direitos a sério, p. 137).

${ }^{108}$ CARVALHO NETTO, Menelick de. A hermenêutica constitucional sob o paradigma do Estado Democrático de Direito. Revista Notícia do Direito Brasileiro, p. 249.
} 


\subsection{A eficácia dos princípios fundamentais de proteção ao trabalhador}

Quanto à questão da eficácia dos princípios, Menelick afirma que estes são normas jurídicas que "operam ativamente no ordenamento ao condicionarem a leitura das regras, suas contextualizações e inter-relações, e ao possibilitarem a integração construtiva da decisão adequada de um hard case $e^{109,}$.

Observa-se que os princípios jurídicos possuem uma característica ou conteúdo normativo diferente das regras jurídicas, e que, portanto, "não podem, em nenhum caso, ganhar aplicação de regra, ao preço de produzirem injustiças que subvertam a crença na

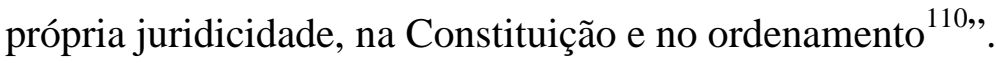

\section{Como destaca Eduardo Marques Vieira Araújo:}

A realidade do mundo do trabalho hodierno afigura-se conturbada diante de séries de violações aos preceitos constitucionais que definem os direitos sociais. A instabilidade da economia vem provocando o atropelamento dos valores sociais e a disseminação da proposta derrogatória ${ }^{111}$.

Araújo destaca que "todas as normas constitucionais referentes à tutela do obreiro compõe o microssistema constitucional de proteção ao trabalhador ${ }^{112}$ ". Segundo o autor, esse microssistema reflete a própria essência e finalidade do Direito do Trabalho, qual seja, "a preservação e tutela do hipossuficiente". Integrariam esse microssistema, por

\footnotetext{
${ }^{109}$ CARVALHO NETTO, Menelick de. A hermenêutica constitucional sob o paradigma do Estado Democrático de Direito. Revista Notícia do Direito Brasileiro, p. 245.

${ }^{110}$ CARVALHO NETTO, Menelick de. A hermenêutica constitucional sob o paradigma do Estado Democrático de Direito. Revista Notícia do Direito Brasileiro, p. 250.

111 ARAÚJO, Eduardo Marques Vieira. Movimentos sociais e a verdadeira valorização do trabalho sob a perspectiva constitucional. Trabalho e Movimentos Sociais. Belo Horizonte: Del Rey, 2008, p. 85.

112 ARAÚJO, Eduardo Marques Vieira. Movimentos sociais e a verdadeira valorização do trabalho sob a perspectiva constitucional. Trabalho e Movimentos Sociais, p. 73.
} 
exemplo, normas constitucionais que prevêem a dignidade da pessoa humana, os valores sociais do trabalho e a garantia do desenvolvimento nacional ${ }^{113}$.

Na visão desse autor, "as normas trabalhistas são meios de consecução do desenvolvimento social, uma vez que regulam o exercício da atividade laborativa balizadas pelo princípio da dignidade humana ${ }^{114 ", ~}$ Diante disso é que a Constituição Federal de 1988 inseriu os chamados direitos sociais dentro da categoria dos direitos e garantias fundamentais.

Importante decisão judicial citada por José Eymard Loguércio exemplifica a eficácia dos princípios de proteção ao trabalhador num caso concreto:

No ERR-439.041/1998, a Egréria Subseção I do Tribunal Superior do Trabalho acolheu o voto do Eminente Ministro João Oreste Dalazen, assegurando a reintegração de empregado portador do vírus HIV, no reconhecimento também de dispensa discriminatória. Na decisão fez-se a seguinte afirmação: 'O repúdio à atitude discriminatória, objeto fundamental da República Federativa do Brasil (art. $3^{\circ}$, IV), e o próprio respeito à dignidade da pessoa humana, fundamento basilar do Estado Democrático de Direito (art. $1^{\circ}$, inciso III), sobrepõem-se à própria inexistência de dispositivo legal que assegure ao trabalhador portador de vírus HIV estabilidade no emprego ${ }^{115}$.

A decisão exposta mostra como os princípios de proteção ao trabalhador podem, diante de uma adequada postura do aplicador do direito, apresentar eficácia direta diante de casos reais. Ao se decidir, nessa situação, pela reintegração do empregado portador do vírus HIV, mesmo que não houvesse qualquer tipo de dispositivo legal prevendo tal

\footnotetext{
113 “O desenvolvimento de uma nação não pode ser mensurado considerando-se apenas os padrões de produtividade. Deve-se observar o desenvolvimento em sentido amplo, analisando todos os seus aspectos: saúde, educação, trabalho, economia e bem-estar" (ARAÚJO, Eduardo Marques Vieira. Movimentos sociais e a verdadeira valorização do trabalho sob a perspectiva constitucional. Trabalho e Movimentos Sociais, p. 75).

114 ARAÚJO, Eduardo Marques Vieira. Movimentos sociais e a verdadeira valorização do trabalho sob a perspectiva constitucional. Trabalho e Movimentos Sociais, p. 75.

${ }^{115}$ LOGUÉRCIO, José Eymard. A nova arquitetura para o sindicalismo no Brasil: a reconstrução da autonomia privada. Os novos horizontes do direito do trabalho: homenagem ao Ministro José Luciano de Castilho Pereira. São Paulo: Ltr, 2005, p. 426.
} 
medida, não houve a criação e aplicação retroativa de um novo direito, mas se entendeu que havia um direito do empregado - vedação à dispensa discriminatória - pré-existente à decisão.

\section{Conforme explica Araújo:}

Se a doutrina e a jurisprudência avançam no sentido de reconhecer a aplicação horizontal dos direitos fundamentais nas relações individuais de trabalho, o mesmo deve ocorrer com as relações coletivas inseridas no texto constitucional igualmente sob a proteção dos direitos e garantias fundamentais ${ }^{116}$.

A decisão do TRT da $15^{\text {a }}$ Região sobre o caso Embraer, nesse sentido, se reveste de grande importância, não pelo dispositivo da decisão em si, que manteve as dispensas, mas pelo fato de ter declarado abusiva a dispensa coletiva realizada pela empresa, revelando assim "importante preocupação com o direito ao trabalho e com o papel dos sindicatos na dinâmica laboral ${ }^{117,}$.

\section{Como expõe Ricardo Lourenço Filho:}

Mas talvez o maior valor da decisão do Tribunal Regional do trabalho esteja no que ela representa. É um valor simbólico. Ela corresponde a uma reação do direito à dinâmica da econômica. Em outras palavras, certamente mais precisas, ela representa uma reação do sistema do direito às irritações oriundas do sistema econômico. A decisão nos provoca a pensar o contexto principalmente em face da crise econômica - e a própria relação entre direito e econômica. Ela é o reflexo da interdependência entre os dois sistemas ${ }^{118}$.

Segundo Lourenço Filho, essa interdependência entre direito e economia não nos permite mais pensar a relação de emprego como um mero conflito entre capital e trabalho, mas obriga a reconhecer que as decisões econômicas apresentam repercussões no

\footnotetext{
${ }^{116}$ LOGUÉRCIO, José Eymard. A nova arquitetura para o sindicalismo no Brasil: a reconstrução da autonomia privada. Os novos horizontes do direito do trabalho: homenagem ao Ministro José Luciano de Castilho Pereira, p. 426.

117 LOURENÇO FILHO, Ricardo. A constituição entre o trabalho e a economia: o caso Embraer. In Constituição e Democracia. Brasília: Março, ano III, nº. 30, pg. 03, 2009.

11 LOURENÇO FILHO, Ricardo. A constituição entre o trabalho e a economia: o caso Embraer. In Constituição e Democracia. Brasília: Março, ano III, nº. 30, pg. 03, 2009.
} 
campo do direito e vice-versa. Assim, justamente em momentos de crise econômica, podemos visualizar como a proteção jurídica à dispensa arbitrária se mostra reduzida ou insuficiente ${ }^{119}$.

De acordo com a decisão do Ministro Presidente do TST, Milton de Moura

França, sobre o caso Embraer:

Não encontra agasalho, igualmente a afirmativa de que teria sido violado o art. $7^{\circ}, \mathrm{I}$, da Constituição Federal, que, relembre-se, ainda depende até mesmo de regulamentação. O dispositivo, ao contrário do que se pensa, não assegura estabilidade ou garantia de emprego e muito menos garante, de imediato, pagamento de indenização, pelo simples fato de que fixação do valor desse título depende de lei complementar, que, lamentavelmente, ainda não foi objeto de deliberação pelo Congresso Nacional ${ }^{120}$.

Na fundamentação de sua decisão, o Ministro privilegia os princípios constitucionais da livre iniciativa e do regular exercício da atividade econômica, considerando assim legítimas as dispensas efetivadas pela empresa, e condiciona a eficácia da norma de vedação à dispensa arbitrária à edição de lei complementar que venha a regulamentar sua aplicação.

Porém, conforme afirma Lourenço Filho:

O constituinte de 1987/1988, ao consagrar o princípio da livre iniciativa, estabeleceu também o direito dos trabalhadores urbanos e rurais á proteção contra a dispensa arbitrária. A previsão constitucional de que essa garantia deve ser regulamentada em lei complementar não pode impedir a efetividade da proteção, especialmente em caso de abuso do direito do empregador de dispensar os trabalhadores. Ou seja, na hipótese de abuso da própria livre iniciativa $^{121}$.

Deve-se observar que, segundo disposto no art. $5^{\circ}, \S 1^{\circ}$, da Constituição

Federal, as normas que definem os direitos e garantias fundamentais têm aplicabilidade

119 LOURENÇO FILHO, Ricardo. A constituição entre o trabalho e a economia: o caso Embraer. In Constituição e Democracia. Brasília: Março, ano III, nº. 30, pg. 03, 2009.

120 TRIBUNAL SUPERIOR DO TRABALHO. Ministro Presidente do TST, Milton de Moura França. Processo: AG-ES - 207660/2009-000-00-00.7, Divulgado no DEJT 14-04-2009.

121 LOURENÇO FILHO, Ricardo. A constituição entre o trabalho e a economia: o caso Embraer. In Constituição e Democracia. Brasília: Março, ano III, nº. 30, pg. 03, 2009. 
imediata. Reconhecendo os direitos sociais - como o do art. $7^{\circ}$, I - como direitos fundamentais, por estarem definidos no Título II do texto constitucional, estes também se revestem dessa imediata aplicabilidade, sendo assim eficazes independentemente da previsão de sua regulamentação por lei complementar ${ }^{122}$.

\section{Conforme explica Ingo Wolfgang Sarlet::}

A Constituição de 1988 - e isto pode ser tido como mais um de seus méritos - acolheu os direitos fundamentais sociais expressamente no título II (Dos Direitos e Garantias Fundamentais), concedendo-lhes capítulo próprio e reconhecendo de forma inequívoca o seu "status" de autênticos direitos fundamentais ${ }^{123}$.

Assim, "é hora de tornar efetiva a proteção conferida pelo constituinte originário, em atenção ao também constitucional mandamento de aplicabilidade imediata dos direitos fundamentais ${ }^{124 ، .}$. E justamente na tarefa de buscar a proteção e efetivação dos direitos fundamentais dos trabalhadores é que se revela também a importância do papel desempenhado pelo sindicato.

\subsection{O papel do sindicato}

Um dos principais caminhos na busca da construção de limites, sejam estes gerais ou específicos para cada caso, para a prática da dispensa coletiva de trabalhadores é a atuação sindical. Conforme destaca Salomão, o papel do sindicato mostra-se ainda mais

\footnotetext{
${ }^{122}$ Embora se afirme no art. $7^{\circ}, \mathrm{I}$, da Constituição Federal de 1988 que a proibição à dispensa arbitrária se dará nos termos de lei complementar, não pode se negar todo e qualquer efeito ao dispositivo pelo fato desta lei ainda não ter sido editada, visto que revela importante princípio de proteção e valorização do trabalho posto pelo legislador constituinte.

${ }^{123}$ SARLET, Ingo Wolfgang. Os direitos fundamentais sociais na Constituição de 1988. Disponível em < http://www.direitopublico.com.br/pdf/REVISTA-DIALOGO-JURIDICO-01-2001-INGO-SARLET.pdf>. Acesso em 25 de junho, 2009, p. 17.

124 LOURENÇO FILHO, Ricardo. A constituição entre o trabalho e a economia: o caso Embraer. In Constituição e Democracia. Brasília: Março, ano III, nº. 30, pg. 03, 2009.
} 
fundamental diante da inexistência no ordenamento jurídico nacional de um regime específico de dispensa coletiva:

Diante da ausência de amparo legal que regulamente as dispensas coletivas, os Sindicatos possuem o papel de buscar através das negociações coletivas, a inserção de cláusulas de estabilidade e cláusulas que, de alguma forma, evitem que ocorram as dispensas em massa ${ }^{125}$.

Da mesma forma, observa Araújo que "o ordenamento trabalhista não consegue prever as peculiaridades específicas das diversas empresas e categorias. Cabe aos sindicatos complementá-lo, por meio da atuação negocial ${ }^{126 "}$.

O já citado voto do Desembargador José Antonio Pancotti, relator do processo referente ao caso Embraer no TRT, revela também essa idéia:

Em todo caso, a falta de regramento da matéria tem sido contornada com a introdução de cláusulas em acordos e convenções coletivas de trabalho que estabelecem os mais variados critérios para a demissão coletiva. Estes critérios normativos inspiram-se geralmente nos costumes, como é o caso dos PDV's, ou nas diretrizes da própria Convenção 158 da Organização Internacional do Trabalho ${ }^{127}$.

Ressaltando a importância do sindicato, Túlio Viana aponta este como a principal fonte do Direito do Trabalho, tanto num aspecto material, buscando a criação de novas normas, como também num aspecto formal, pois o próprio sindicato, através da convenção coletiva, pode criar suas normas ${ }^{128}$.

\footnotetext{
${ }^{125}$ SALOMÃO, Claudia Regina. A dispensa coletiva no ordenamento jurídico brasileiro e a influência da Convenção n. 158 da OIT. Legislação do Trabalho, p. 450.

${ }^{126}$ ARAÚJO, Eduardo Marques Vieira. Movimentos sociais e a verdadeira valorização do trabalho sob a perspectiva constitucional. Trabalho e Movimentos Sociais, p. 81.

127 TRIBUNAL REGIONAL DO TRABALHO DA $15^{\mathrm{a}}$ REGIÃO. Seção de Dissídios Coletivos. Processo 00309-2009-000-15-00-4. Decisão 000333/2009-PADC, voto do Desembargador relator José Antonio Pancotti, pg. 32. Publicado em 30/03/2009.

128 VIANA, Márcio Túlio. O sindicato e a proteção ao emprego. Direito coletivo do trabalho em uma sociedade pós-industrial. São Paulo: Ltr, 2003, p. 354.
} 
Assim, a atuação sindical deve se realizar em dois âmbitos distintos: num sentido mais amplo, realizando pressão política e exigências ao Estado, no sentido deste promulgar mais normas ou medidas de proteção ao trabalhador e ao emprego ${ }^{129}$, e num âmbito mais reduzido, atuando diante de casos específicos através da negociação coletiva.

A efetiva atuação do sindicato nesses dois âmbitos é de igual importância, uma vez que:

Muitas vezes, as pressões que não conseguiram evitar a norma se deslocam do congresso para a fábrica, e passam a atuar no momento de sua aplicação. Com isso, a norma passa a dizer menos, ou valer menos, ou mesmo a não valer nada; é como se o poder econômico reassumisse o papel que havia delegado aos representantes políticos ${ }^{130}$.

As pressões ou interesses econômicos geralmente se contrapõem à maior participação efetiva do sindicato, visto que a garantia de mais direitos aos trabalhadores - ou maior rigidez atribuída a estes - e a maior proteção ao emprego significam uma menor flexibilização das relações de trabalho e um maior gasto de produção para as empresas. Com isso, o sindicato deve atuar não só no sentido de pressionar o Estado para a adoção de uma política de efetiva proteção e valorização do trabalho - e conseqüentemente do trabalhador - e para criação de novas normas de proteção ${ }^{131}$, mas também buscar atribuir efetividade as normas já existentes, principalmente no interior da empresa ou estabelecimento, onde normalmente se verificam as maiores violações aos direitos dos empregados.

Conforme explica Viana, referindo-se a importância do papel do sindicato:

\footnotetext{
${ }^{129}$ Como afirma VIANA, a própria criação da CLT foi uma resposta do governo de Getúlio Vargas as pressões sindicais que já existiam na época (VIANA, Márcio Túlio. O sindicato e a proteção ao emprego. Direito coletivo do trabalho em uma sociedade pós-industrial, p. 354).

130 VIANA, Márcio Túlio. O sindicato e a proteção ao emprego. Direito coletivo do trabalho em uma sociedade pós-industrial, p. 354.

131 Segundo Viana: "proteger o emprego não é só proteger o emprego. É também proteger o sindicato e as condições de trabalho" (VIANA, Márcio Túlio. O sindicato e a proteção ao emprego. Direito coletivo do trabalho em uma sociedade pós-industrial, p. 357).
} 
Para que a lei realmente funcione, ele tem de estar ao lado do trabalhador, ajudando-o a defender-se. Suas armas de luta - especialmente a greve atuariam como uma sanção a mais, devolvendo ao direito um pouco da efetividade perdida ${ }^{132}$.

Nesse sentido, a própria Constituição Federal de 1988 reconheceu a importância do papel desempenhado pelo sindicato, estabelecendo em seu art. $8^{\circ}$, III, que "ao sindicato cabe a defesa dos direitos e interesses coletivos ou individuais da categoria, inclusive em questões judiciais ou administrativas". Além disso, o disposto no inciso VI do mesmo artigo revela a preocupação do legislador constituinte em garantir o equilíbrio das partes na negociação coletiva e evitar que os acordos ou convenções coletivas de trabalho se apresentam como legítimas imposições da vontade do empregador, estabelecendo assim que “é obrigatória a participação dos sindicatos nas negociações coletivas de trabalho".

Não obstante, o Ministro Milton de Moura França destacou em sua decisão que:

[...] também não procede, por absoluta falta de amparo legal, o argumento de que a requerente estava obrigada a negociar, com o sindicato profissional, a dispensa dos trabalhadores. Não há, especificamente, nenhum dispositivo normativo que lhe imponha essa obrigação ${ }^{133}$.

Deve se atentar que as normas do art. $8^{\circ}$, incisos III e VI, dizem respeito a direitos fundamentais, conforme exposto no subcapítulo anterior, e assim apresentam aplicabilidade imediata, ainda que na ausência de uma mais detalhada ou pormenorizada regulamentação por lei específica.

Assim, em sentido oposto à manifestação do Ministro Presidente do TST, o Desembargador José Antonio Pancotti expôs que:

\footnotetext{
132 VIANA, Márcio Túlio. O sindicato e a proteção ao emprego. Direito coletivo do trabalho em uma sociedade pós-industrial, p. 354.

133 TRIBUNAL SUPERIOR DO TRABALHO. Ministro Presidente do TST, Milton de Moura França. Processo: AG-ES - 207660/2009-000-00-00.7, Divulgado no DEJT 14-04-2009.
} 
[...] sob pena de configurar abuso do poder econômico, não se pode reconhecer discricionariedade absoluta do empregador para as demissões coletivas, sem que haja uma ampla negociação com os entes sindicais respectivos ${ }^{134}$.

\subsubsection{Cenário atual: crise ou decadência?}

No Brasil, até o final da década de 1980, vigorava um modelo trabalhista de inspiração autoritária, onde o próprio Estado controlava todos os espaços de atuação sindical, retirando a autonomia e a liberdade dos sindicatos ${ }^{135}$.

Mesmo com o fim da Era Vargas e o retorno à democracia, ainda sobreviveram na legislação trabalhista diversos aspectos corporativistas. Assim, nos dizeres de Álvares da Silva:

$\mathrm{O}$ regime criado na era Vargas e sedimentado na CLT sobreviveu à democracia reinstalada pela Constituição de 1946 e permaneceu inalterado até o golpe de 1964. Conviveu com a legislação arbitrária da época, não foi revogado por nenhum ato institucional ou decreto-lei. Permaneceu intrépido até a Constituição de 1988, quando, para surpresa de todos, ainda sobreviveu ${ }^{136}$.

Somente na década de 1980, com a redemocratização e o crescimento econômico nacional, poderia se observar "uma recuperação de espaços de autonomia coletiva, ampliando-se o círculo de negociações e de contratação coletivas nos setores mais

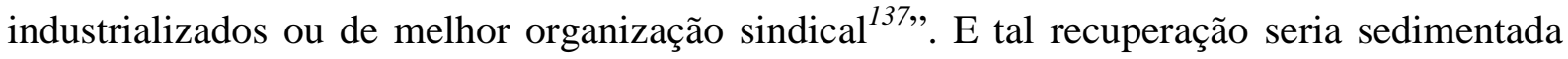
pela Constituição Federal de 1988, ainda que de forma contraditória, uma vez que amplia

134 TRIBUNAL REGIONAL DO TRABALHO DA 15 ${ }^{\mathrm{a}}$ REGIÃO. Seção de Dissídios Coletivos. Processo 00309-2009-000-15-00-4. Decisão 000333/2009-PADC, voto do Desembargador relator José Antonio Pancotti, pg. 32. Publicado em 30/03/2009.

${ }^{135}$ LOGUÉRCIO, José Eymard. A nova arquitetura para o sindicalismo no Brasil: a reconstrução da autonomia privada. Os novos horizontes do direito do trabalho: homenagem ao Ministro José Luciano de Castilho Pereira, p. 422.

${ }^{136}$ ÁLVARES DA SILVA. Antônio. Marcos legais do corporativismo no Brasil. O mundo do trabalho: crise e mudança no final do século. São Paulo: Página Aberta, 1994, p. 123.

${ }^{137}$ LOGUÉRCIO, José Eymard. A nova arquitetura para o sindicalismo no Brasil: a reconstrução da autonomia privada. Os novos horizontes do direito do trabalho: homenagem ao Ministro José Luciano de Castilho Pereira, p. 425. 
esses espaços de autonomia e, ao mesmo tempo, limita a liberdade sindical, mantendo o sistema confederativo, a contribuição sindical compulsória, a organização por categorias profissionais ou econômicas e o sindicato único.

De acordo com Álvares da Silva, a Constituição Federal de 1988 apresenta uma grande dessintonia com o seu tempo, em relação à questão sindical, uma vez que traz elementos corporativistas de inspiração autoritária para dentro do ordenamento jurídico de um Estado democrático. Para Loguércio, tal descompasso, no âmbito nacional, se deve a razões históricas que remontam ao processo de industrialização do país ${ }^{138}$, onde, como afirma Ignácio Rangel, nasceu uma “contradição entre o seu lado moderno, isto é, capitalista, e o seu lado arcaico, isto é, feudal ${ }^{139, "}$.

Essa dessintonia das normas sobre o sindicato não se dava somente em relação às demais normas jurídicas internas, mas também podia ser observada em relação a importantes diplomas internacionais, desde a Declaração Universal dos Direitos Humanos ${ }^{140}$ e da importante Convenção n. 87 da OIT $^{141}$, não ratificada pelo Brasil, que trata da liberdade sindical e proteção do direito sindical.

Além da permanência de traços corporativistas no texto constitucional democrático de 1988, ao lado de normas que reconhecem uma maior autonomia e

\footnotetext{
${ }^{138}$ Como afirma Loguércio: "Nota-se, portanto, a convivência por longas décadas, e algumas ainda próximas de nós, de um Brasil arcaico e moderno de trabalho escravo e livre e de trabalho livre e assalariado, com profundas assimetrias e enormes disparidades na distribuição e circulação de Direitos, bem como na capacidade de organização da solidariedade dos trabalhadores em sua perspectiva emancipatória" (LOGUÉRCIO, José Eymard. A nova arquitetura para o sindicalismo no Brasil: a reconstrução da autonomia privada. Os novos horizontes do direito do trabalho: homenagem ao Ministro José Luciano de Castilho Pereira, p. 423).

${ }^{139}$ LOGUÉRCIO, José Eymard. A nova arquitetura para o sindicalismo no Brasil: a reconstrução da autonomia privada. Os novos horizontes do direito do trabalho: homenagem ao Ministro José Luciano de Castilho Pereira, p. 423.

${ }^{140} \mathrm{O}$ art. 23, IV, da referida Declaração dispõe: "IV) Todo homem tem direito a organizar sindicatos e a neles ingressar para proteção de seus interesses".

${ }^{141}$ Além dessa, outras Convenções da OIT também trataram de diferentes aspectos da questão sindical, como a Convenção n. 98, n. 151 e a n. 154.
} 
participação do sindicato, outro obstáculo a real e efetiva atuação sindical, afirmam grande parte dos juristas trabalhistas, reside na própria crise ou decadência pela qual atravessa o sindicalismo brasileiro.

Conforme expõe Reginaldo Melhado:

[...] o processo de globalização acentua, e em algumas ocasiões exaspera, os problemas e as dúvidas suscitadas sobre o papel do sindicato ao longo da evolução que sofreu o mundo do trabalho nesses últimos decênios, como é o caso da crise de representação do sindicato ${ }^{142}$.

$\mathrm{Na}$ visão de Rüdiger, essa crise sindical se reflete em dois fatores fundamentais: "o deslocamento da fonte principal do direito do trabalho para a autonomia privada e os desafios para a representação de interesses no âmbito do trabalho reestruturado ${ }^{143}$ ". Assim, com a autonomia privada representando a principal fonte trabalhista, no lugar da autonomia coletiva, ocorre que a atuação sindical dentro da negociação coletiva perde muito de sua força, o que desvirtua o próprio sentido dessa negociação ${ }^{144}$.

Nesse sentido:

[...] a negociação coletiva não é mais instrumento de emancipação dos trabalhadores, não mais expressão de seu 'contra-poder', como foi visto. A negociação enquanto 'pequena narrativa' degrada para pura técnica de solução de problemas econômicos conjunturais, é pervertida para servir de instrumento jurídico de desregulamentação de direitos trabalhistas ${ }^{145}$.

\footnotetext{
${ }^{142}$ MELHADO, Reginaldo. Os sindicatos e a mundialização do capital: desafios, horizontes e utopias. Direito coletivo do trabalho em uma sociedade pós-industrial. São Paulo: Ltr, 2003, p. 87.

${ }^{143}$ RÜDIGER, Dorothee Susanne. Emancipação em rede: condições jurídicas para a defesa coletiva dos direitos dos trabalhadores no século XXI. Direito coletivo do trabalho em uma sociedade pós-industrial. São Paulo: Ltr, 2003, p. 72.

144 Segundo Rüdiger, ocorre hoje uma perversão da negociação coletiva, visto que os direitos e garantias conquistadas pelos trabalhadores ao longo dos séculos acabam se enfraquecendo ou se esfarelando, submetendo as relações trabalhistas às nuances e exigências da conjuntura econômica e política atual (RÜDIGER, Dorothee Susanne. Emancipação em rede: condições jurídicas para a defesa coletiva dos direitos dos trabalhadores no século XXI. Direito coletivo do trabalho em uma sociedade pós-industrial, p. 76).

${ }^{145}$ RÜDIGER, Dorothee Susanne. Emancipação em rede: condições jurídicas para a defesa coletiva dos direitos dos trabalhadores no século XXI. Direito coletivo do trabalho em uma sociedade pós-industrial. São Paulo: Ltr, 2003, p. 72.
} 
Estando o sindicato enfraquecido, observa-se que a presunção de igualdade de condições entre os contratantes coletivos não mais se verifica na prática, tornando assim os acordos ou convenções coletivas como meros contratos de adesão, com cláusulas já préestabelecidas pelo empregador e impostas aos empregados, parte economicamente mais fraca.

Assim, observa Melhado:

A reificação da idéia de expansão macroeconômica legitima ações estratégicas e tácitas de ab-rogação de direitos sociais e inibe ou freia movimentos reivindicatórios. O pressuposto das negociações coletivas passa a ser a racionalidade do crescimento econômico que, em última análise, abre caminho à trilha da expansão do capital ${ }^{146}$.

Dessa forma, nesse cenário "em que o capital se torna cada vez mais forte, a negociação pode esconder a submissão - gerando leis não só mais precarizantes, como mais legitimadas, e portanto mais efetivas ${ }^{147, "}$.

Porém, para outros doutrinadores trabalhistas, como Túlio Viana, o quadro atual não representaria somente uma crise, mas um verdadeiro declínio do sindicalismo, no sentido que as empresas já conseguem "produzir sem reunir" - descentralização produtiva - e ainda manter seu controle, solucionando assim o paradoxo do sistema capitalista que originou os sindicatos, ao reunir diversos trabalhadores homogêneos numa mesma fábrica concentrada $^{148}$.

\footnotetext{
${ }^{146}$ MELHADO, Reginaldo. Os sindicatos e a mundialização do capital: desafios, horizontes e utopias. Direito coletivo do trabalho em uma sociedade pós-industrial, p. 88.

${ }^{147}$ VIANA, Márcio Túlio. Poder diretivo e sindicato: entre a opressão e a resistência. Os novos horizontes do direito do trabalho: homenagem ao Ministro José Luciano de Castilho Pereira, p. 407.

${ }^{148}$ De acordo com Túlio Viana: “[...]É interessante notar como foi a própria fábrica que o fez nascer, na medida em que reuniu, num mesmo ambiente, sofrimentos e sonhos iguais. Era uma espécie de anticorpo, gerado no próprio corpo do doente. Uma contradição do sistema, ou mais precisamente de um modo de ser do sistema, representado pela fábrica concentrada" (VIANA, Márcio Túlio. Poder diretivo e sindicato: entre a opressão e a resistência. Os novos horizontes do direito do trabalho: homenagem ao Ministro José Luciano de Castilho Pereira, p. 395).
} 
Segundo Viana, o principal sintoma desse declínio se reflete na postura ou estratégia adotada pelos sindicatos atuais, uma vez que estes, devido ao seu enfraquecimento, não buscam mais a conquista de novos espaços de atuação ou pressionam pela criação de novos direitos de proteção ao trabalhador e ao emprego ${ }^{149}$, mas passam a "bater em retirada, passo a passo, defendendo o que for possível ${ }^{150,}$.

No mesmo sentido, expõe Menezes:

Não havendo mais esperanças para a promoção do trabalho e da dignidade do trabalhador, a saída consistiria numa paranóica resistência a qualquer modificação, como se tal atitude correspondesse automaticamente ao interesse hipossuficiente. Os pilares do corporativismo seriam um porto seguro no qual os trabalhadores poderiam ancorar em segurança, permanecendo incólumes à dinâmica histórica, e usufruindo de um welfare state cristalizado no tempo ${ }^{151}$.

\subsubsection{Novos caminhos para o sindicalismo no Brasil}

Hoje, a realidade observada é de uma verdadeira precarização das relações de trabalho, caracterizada também pelo enfraquecimento do sindicato ${ }^{152}$, que não conseguiu retomar a força que historicamente detinha, uma vez que os saberes tácitos - ou a qualificação - que possuíam os trabalhadores de outrora, e que representavam seu próprio instrumento de

149 Destaca Melhado: "Convivendo com o desemprego estrutural e a piora das condições de vida dos seus associados, os sindicatos terminam por ceder às pressões de toda uma rede de influencias - desde o próprio capital até uma mídia literalmente confessora dos valores neoliberais, passando naturalmente por governos e instituições políticas - no sentido de admitir a flexibilização do Direito do Trabalho. [...] Isto é feito sob a ameaça do desemprego, com o apoio das novas teorias e políticas governamentais em matéria de salário e de emprego, e também com o consentimento de dirigentes sindicais que julgam que não "há outra saída' ${ }^{149}$." (MELHADO, Reginaldo. Os sindicatos e a mundialização do capital: desafios, horizontes e utopias. Direito coletivo do trabalho em uma sociedade pós-industrial, p. 91).

${ }^{150}$ VIANA, Márcio Túlio. Poder diretivo e sindicato: entre a opressão e a resistência. Os novos horizontes do direito do trabalho: homenagem ao Ministro José Luciano de Castilho Pereira, p. 407.

${ }^{151}$ MENEZES, Mauro de Azevedo. Horizontes da negociação coletiva no Brasil: lineamentos para a construção de uma efetiva cidadania sindical. Os novos horizontes do direito do trabalho: homenagem ao Ministro José Luciano de Castilho Pereira. São Paulo: Ltr, 2005, p. 439.

${ }^{152}$ Uma das razões apontadas por Viana para esse enfraquecimento é a lógica da competitividade instaurada na estruturada empresa, o que gera um ambiente de individualismo crescente, prejudicando, por exemplo, a negociação coletiva. Como afirma o autor: "Cada trabalhador vê no colega - ou no outro grupo - um concorrente que deve ser vencido. Assim, o sentimento de solidariedade ou se parte de vez, ou é canalizado também para a empresa. O trabalhador se torna solidário a ela" (VIANA, Márcio Túlio. Poder diretivo e sindicato: entre a opressão e a resistência. Os novos horizontes do direito do trabalho: homenagem ao Ministro José Luciano de Castilho Pereira, p. 404). 
resistência e barganha com o empregador, hoje "são utilizados pela própria empresa - que já não os teme, pois tem o controle total do jogo ${ }^{153}$ ".

Segundo Rüdiger, no "contexto das mudanças estruturais do capitalismo, o direito do trabalho é exposto a um processo de esfarelamento que atinge não somente os direitos individuais dos trabalhadores, como também modifica o direito coletivo ${ }^{154}$."

Assim, explica Loguércio, a superação da crise que enfrenta o sindicalismo hoje passa pela necessidade de reconstrução da autonomia coletiva privada ${ }^{155}$, buscando-se assegurar os princípios fundamentais referentes à atuação e a liberdade sindical. Para o autor, a real compreensão da autonomia coletiva pressupõe:

[...] o agir em conformidade com a Constituição e com a máxima extensão dada aos princípios adotados no plano da OIT e das normas internacionais no plano da Liberdade Sindical e da negociação coletiva. [...] o papel da jurisdição há de ser o de promover os valores reconhecidos nos planos internacional e interno, assegurando a procedimentalização (direito de informação; direito de resposta em tempo razoável; direito de negociação com entidades representativas) e coibindo práticas abusivas (práticas antisindicais). ${ }^{156}$

A dificuldade do sindicato atual em se apresentar como um "contra-poder"

às pressões econômicas deve-se essencialmente à nova organização empresarial em rede.

Segundo Rüdiger, a estrutura sindical não evoluiu ou não acompanhou no mesmo ritmo as evoluções sociais e econômicas de toda comunidade, seja porque a própria legislação

\footnotetext{
${ }^{153}$ VIANA, Márcio Túlio. Poder diretivo e sindicato: entre a opressão e a resistência. Os novos horizontes do direito do trabalho: homenagem ao Ministro José Luciano de Castilho Pereira, p. 403.

${ }^{154}$ RÜDIGER, Dorothee Susanne. Emancipação em rede: condições jurídicas para a defesa coletiva dos direitos dos trabalhadores no século XXI. Direito coletivo do trabalho em uma sociedade pós-industrial, p. 68.

${ }^{155}$ No mesmo sentido, Rüdiger expõe que é necessário "destruir a imagem ingênua da autonomia privada coletiva como sendo um campo em que partes iguais normatizam relações do trabalho (ou outras relações sociais) em pé de igualdade". (RÜDIGER, Dorothee Susanne. Emancipação em rede: condições jurídicas para a defesa coletiva dos direitos dos trabalhadores no século XXI. Direito coletivo do trabalho em uma sociedade pós-industrial, p. 73).

${ }^{156}$ LOGUÉRCIO, José Eymard. A nova arquitetura para o sindicalismo no Brasil: a reconstrução da autonomia privada. Os novos horizontes do direito do trabalho: homenagem ao Ministro José Luciano de Castilho Pereira, p. 433.
} 
trabalhista, de traços corporativistas, assim não permitiu, como também pela própria inércia dos sindicatos ${ }^{157}$.

Dessa forma, "grandes organizações sindicais ainda obedecem à idéia da territorialidade e de categorias econômicas ${ }^{158,}$, idéia essa que é gradativamente desconstruída pelas próprias empresas, dentro do já citado processo de descentralização da produção, motivada muitas vezes visando ao enfraquecimento do sindicato.

Assim, afirma Melhado que a estrutura sindical concebida atualmente não tem capacidade de formular respostas a essa nova organização da produção e a nova lógica de mercado criada pela globalização, pois os movimentos sindicais ainda "concebem sua atuação dentro de marcos estatais ${ }^{159,}$. Com isso, aponta o autor, o sindicato não consegue construir uma estratégia política para combater, por exemplo, a questão da deslocalização do capital, caracterizada pelo deslocamento de fábricas para outras regiões em busca de mão-de-obra mais barata e legislação trabalhista mais branda ${ }^{160}$.

Para Túlio Viana, que entende a atual situação do movimento sindical no país como em verdadeiro declínio, mais do que meramente uma crise, há a necessidade de não somente uma nova concepção de sindicato, mas "um sindicato inteiramente novo, nascido das próprias cinzas $^{161,}$. Tal solução mostra-se adequada uma vez que o inimigo ou desafio do

\footnotetext{
${ }^{157}$ RÜDIGER, Dorothee Susanne. Emancipação em rede: condições jurídicas para a defesa coletiva dos direitos dos trabalhadores no século XXI. Direito coletivo do trabalho em uma sociedade pós-industrial, p. 72-73.

${ }^{158}$ RÜDIGER, Dorothee Susanne. Emancipação em rede: condições jurídicas para a defesa coletiva dos direitos dos trabalhadores no século XXI. Direito coletivo do trabalho em uma sociedade pós-industrial, p. 72-73.

${ }^{159}$ MELHADO, Reginaldo. Os sindicatos e a mundialização do capital: desafios, horizontes e utopias. Direito coletivo do trabalho em uma sociedade pós-industrial, p. 89.

${ }^{160}$ Para Melhado: "A capacidade de deslocalização adquirida pelas empresas na economia pós-fordista afeta diretamente os sindicatos. Capazes de uma mobilidade quase virtual, as grandes companhias fundem-se ou associam-se a outras, interpenetram-se, vagueiam pelo planeta em busca de um domicílio eletivo mais vantajoso." (MELHADO, Reginaldo. Os sindicatos e a mundialização do capital: desafios, horizontes e utopias. Direito coletivo do trabalho em uma sociedade pós-industrial, p. 90).

${ }^{161}$ VIANA, Márcio Túlio. Poder diretivo e sindicato: entre a opressão e a resistência. Os novos horizontes do direito do trabalho: homenagem ao Ministro José Luciano de Castilho Pereira, p. 411.
} 
sindicalismo atual não se encontra somente do lado oposto, representado pela empresa ou pelo mercado, mas se situa também no interior de sua própria estrutura, e assim, somente com a sua completa revitalização, surgindo um sindicato mais forte ${ }^{162}$ e em sintonia com a nova realidade econômica e social, poderia se transformar esse quadro.

Menezes destaca que essa realidade só será mudada a partir da busca de uma autêntica cidadania sindical, visto que:

Sem a presença efetiva da representação coletiva trabalhista dentro da empresa, o sindicalismo fica a meio caminho, ameaçado pelas tentações burocráticas e formais decorrentes do distanciamento físico dos dirigentes com o chão da fábrica ${ }^{163}$.

Concluindo, Melhado expõe, no mesmo sentido dos autores aqui já citados, que o sindicalismo do Brasil, a fim de buscar solucionar seus erros e imperfeições e superar os desafios impostos pela nova conjuntura econômica e política mundial, deve "forjar uma nova cultura e reconstruir suas estratégias ${ }^{164,}$, desenhando um novo horizonte político ${ }^{165}$ para o movimento, tendo como objetivo a construção de uma nova sociedade igualitária e justa, “capaz de superar a barbárie capitalista em que nos enfiamos neste início de século ${ }^{166, "}$.

\footnotetext{
${ }^{162}$ Como explica Túlio Viana, "se o sindicato é forte, serão também fortes as regras sobre os pagamentos ou as alterações do contrato". (VIANA, Márcio Túlio. O sindicato e a proteção ao emprego. Direito coletivo do trabalho em uma sociedade pós-industrial, p. 345).

${ }^{163}$ MENEZES, Mauro de Azevedo. Horizontes da negociação coletiva no Brasil: lineamentos para a construção de uma efetiva cidadania sindical. Os novos horizontes do direito do trabalho: homenagem ao Ministro José Luciano de Castilho Pereira, p. 441.

${ }^{164}$ MELHADO, Reginaldo. Os sindicatos e a mundialização do capital: desafios, horizontes e utopias. Direito coletivo do trabalho em uma sociedade pós-industrial, p. 92.

165 Segundo Melhado, os sindicatos "poderão ter o mercado como marco mas não como horizonte" . (MELHADO, Reginaldo. Os sindicatos e a mundialização do capital: desafios, horizontes e utopias. Direito coletivo do trabalho em uma sociedade pós-industrial, p. 92).

${ }^{166}$ MELHADO, Reginaldo. Os sindicatos e a mundialização do capital: desafios, horizontes e utopias. Direito coletivo do trabalho em uma sociedade pós-industrial, p. 92.
} 


\section{CONCLUSÃO}

Os princípios fundamentais de valorização e proteção do trabalho expostos na Constituição, enquanto normas jurídicas, operam ativamente no ordenamento jurídico e condicionam a aplicação das regras diante de um caso concreto. Assim, estabelecem direitos e deveres que pré-existem ao momento da decisão, e que, portanto, não estão sujeitos à discricionariedade do aplicador do direito.

Mesmo quando há uma lacuna legislativa em relação a determinado tema, como a dispensa coletiva, não pode esta ausência ser compreendida pelos aplicadores do direito como uma permissão para a realização dessa prática sem qualquer tipo de limitação.

A Convenção n. 158 da OIT, plenamente compatível com a ordem constitucional brasileira, pode definir um horizonte para a construção de limites à dispensa coletiva, como prever sua possibilidade apenas diante de relevantes motivos econômicos, tecnológicos, estruturais ou análogos, e condicionar sua efetividade à prévia notificação ao Estado e ao sindicato, para que possam ser buscadas medidas alternativas para evitar as dispensas ou atenuar seus efeitos.

A compreensão do poder diretivo do empregador afastada da idéia de um poder potestativo permite a visualização do caráter essencialmente dinâmico do contrato de trabalho, reconhecendo a importância da participação coletiva dos trabalhadores como meio de conquistar maior espaço nessa relação de poder.

Nesse sentido, o sindicato pode desempenhar um importante papel na proteção dos direitos e garantias trabalhistas, buscando por meio de sua efetiva atuação estabelecer limites para a dispensa coletiva em cada caso concreto. Porém, o processo de 
globalização e as mudanças provocadas nas relações de trabalho originaram uma verdadeira crise no sindicalismo brasileiro, uma vez que o sindicato encontra dificuldade em se adequar a essa nova realidade da organização empresarial em rede, distorcendo assim a própria essência da negociação coletiva, não mais representando um instrumento de emancipação dos trabalhadores.

A superação do quadro de crise e o fortalecimento do sindicalismo no país, através da criação de um novo perfil, novas estratégias e um novo horizonte político para o movimento sindical, objetivando o aumento de sua autonomia e de sua atuação, permitirão ao sindicato exercer de forma mais eficaz seu importante papel na negociação coletiva.

Ao ver do presente estudo, as decisões dos tribunais acerca do caso Embraer, de acordo com a teoria de Ronald Dworkin, não traduziram a melhor interpretação construtiva da prática jurídica da comunidade, pois não satisfizeram a exigência de, a um só tempo, assegurar a segurança jurídica e o sentimento de justiça realizada.

Embora a decisão do TRT da $15^{\circ}$ Região tenha reconhecido a abusividade da dispensa coletiva realizada pela Embraer, demonstrando uma preocupação com o direito ao trabalho e com o papel desempenhado pelos sindicatos na negociação coletiva, não atribuiu maior eficácia à proteção constitucional prevista no art. $7^{\circ}$, inciso I.

Reconhecida a atividade interpretativa realizada pelo aplicador do direito como essencial para a implementação de um ordenamento jurídico, não apenas nos casos onde há uma omissão legislativa, exige-se, dentro da nova postura judicial adequada ao paradigma do Estado Democrático de Direito, o esforço dos tribunais na busca da única resposta correta para cada caso concreto. 
Adotada tal postura, deve o aplicador do direito considerar, em sua decisão, o ordenamento jurídico em sua integridade, a fim de adequar os princípios e regras contidas neste às particularidades de cada caso. Há de se observar, dessa forma, que a Constituição de 1988 buscou afirmar, em diversas normas, a valorização e a proteção do trabalho, como pressupostos para o desenvolvimento de uma justiça social. Com isso, a dispensa coletiva, realizada de forma irrestrita, pode vir a representar uma ofensa a essas normas constitucionais.

Reconhece-se assim que, em certos casos, a dispensa coletiva pode figurar como uma medida inevitável para a sobrevivência da empresa. Porém, reconhecer que tal prática pode ser realizada pelo empregador sem qualquer tipo de limitação, uma vez que esta se mostre necessária, implica em admitir que o trabalhador deve se curvar às inconstâncias do mercado, e que os direitos sociais nada valem em tempos de crise. 


\section{REFERÊNCIAS BIBLIOGRÁFICAS}

ÁLVARES DA SILVA. Antônio. Marcos legais do corporativismo no Brasil. O mundo do trabalho: crise e mudança no final do século. São Paulo: Página Aberta, 1994.

ARAÚJO, Eduardo Marques Vieira. Movimentos sociais e a verdadeira valorização do trabalho sob a perspectiva constitucional. Trabalho e Movimentos Sociais. Belo Horizonte: Del Rey, pg. 69-92, 2008.

BELTRAN, Ari Possidonio. Direito do trabalho: limites do poder diretivo e outras questões da atualidade. Revista do Advogado. São Paulo: Junho, ano XXV, n. 82, pg. 10-21, 2005.

BRASIL. Constituição (1998). Constituição da República Federativa do Brasil. Disponível em: < http://www.planalto.gov.br/ccivil_03/constituicao/constituiçao.htm>. Acesso em: $13 \mathrm{de}$ maio, 2009.

CARVALHO NETTO, Menelick de. A hermenêutica constitucional sob o paradigma do Estado Democrático de Direito. Revista Notícia do Direito Brasileiro, Brasília, jul./dez, v. 6, 1998.

CLT. Consolidação das Leis do Trabalho. Disponível em:

<http://www.planalto.gov.br/ccivil/Decreto-Lei/Del5452.htm>. Acesso em: 15 de maio, 2009.

DELGADO, Maurício Godinho. Curso de direito do trabalho, 5.ed., São Paulo: LTr, 2006.

DELGADO, Maurício Godinho. O poder empregatício. São Paulo: LTr, 1996.

DWORKIN, Ronald. Levando os direitos a sério. São Paulo: Martins Fontes, 2002.

DWORKIN, Ronald. O império do direito. São Paulo: Martins Fontes, 1999.

FOLHA ONLINE. Disponível em: < http://www.folha.uol.com.br/> Acesso em 13 de maio, 2009.

GONÇALVES JÚNIOR, Mário. Demissão coletiva. Revista do direito trabalhista.

Fevereiro, ano 13, n. 02, Consulex, 2007, pg. 10-12. 
LOGUÉRCIO, José Eymard. A nova arquitetura para o sindicalismo no Brasil: a reconstrução da autonomia privada. Os novos horizontes do direito do trabalho: homenagem ao Ministro José Luciano de Castilho Pereira. São Paulo: Ltr, 2005, pg. 412-434.

LOURENÇO FILHO, Ricardo. A constituição entre o trabalho e a economia: o caso Embraer. In Constituição e Democracia. Brasília: Março, ano III, nº. 30, pg. 03, 2009.

MELHADO, Reginaldo. Os sindicatos e a mundialização do capital: desafios, horizontes e utopias. Direito coletivo do trabalho em uma sociedade pós-industrial. São Paulo: Ltr, 2003, pg. 81-92.

MELHADO, Reginaldo. Poder e sujeição: os fundamentos da relação de poder entre capital e trabalho e o conceito de subordinação. São Paulo: LTr, 2003.

MENEZES, Mauro de Azevedo. Horizontes da negociação coletiva no Brasil: lineamentos para a construção de uma efetiva cidadania sindical. Os novos horizontes do direito do trabalho: homenagem ao Ministro José Luciano de Castilho Pereira. São Paulo: Ltr, 2005, pg. 435-444.

MESSIAS DA SILVA. Leda Maria. Poder diretivo do empregador, emprego decente e direitos da personalidade. Disponível em $<$ http://www.cesumar.br/mestradodireito/arquivos/volume6/Poder\%20diretivo.pdf $>$ Acesso em: 10 de junho, 2009.

OIT, Convenção n. 158 (1985). Disponível em < http://s.conjur.com.br/dl/convencao-oit158.pdf> Acesso em: 17 de junho, 2009

PROTOCOLO SAN SALVADOR, Protocolo Adicional à Convenção Americana sobre Direitos Humanos em matéria de Direitos Econômicos, Sociais e Culturais. Disponível em < http://www.cidh.oas.org/Basicos/Portugues/e.Protocolo_de_San_Salvador.htm> Acesso em: 08 de julho, 2009.

ROBORTELLA, Luiz Carlos Amorim. Idéias para a reforma da legislação do trabalho. Revista do Advogado. São Paulo: Junho, ano XXV, n. 82, pg. 85-95, 2005.

RODRIGUES, Guilherme Scotti. A afirmação da justiça como a tese da única decisão correta: o enfrentamento da questão do caráter estruturalmente indeterminado do direito moderno. 2008. Dissertação (Mestrado em "Direito, Estado e Constituição). Faculdade de Direito, Universidade de Brasília, Brasília. 
RÜDIGER, Dorothee Susanne. Emancipação em rede: condições jurídicas para a defesa coletiva dos direitos dos trabalhadores no século XXI. Direito coletivo do trabalho em uma sociedade pós-industrial. São Paulo: Ltr, 2003, pg. 63-76.

SALOMÃO, Claudia Regina. A dispensa coletiva no ordenamento jurídico brasileiro e a influência da Convenção n. 158 da OIT. Legislação do Trabalho. São Paulo: Abril, ano 72, n. 04, LTr, 2008.

SARLET, Ingo Wolfgang. Os direitos fundamentais sociais na Constituição de 1988. Disponível em < http://www.direitopublico.com.br/pdf/REVISTA-DIALOGO-JURIDICO01-2001-INGO-SARLET.pdf>. Acesso em 25 de junho, 2009.

SOUTO MAIOR, Jorge Luiz. Convenção 158 da OIT. Dispositivo que veda a dispensa arbitrária é auto-aplicável. Disponível em

<http://jus2.uol.com.br/doutrina/texto.asp?id=5820> Acesso em: 15 de junho, 2009.

SUPREMO TRIBUNAL FEDERAL. Disponível em:

<http://www.stf.jus.br/portal/principal/principal.asp>. Acesso em 15 de junho, 2009.

TRIBUNAL REGIONAL DO TRABALHO DA 15 REGIÃO. Disponível em: <http://www.trt15.jus.br/>. Acesso em: 09 de junho, 2009.

TRIBUNAL SUPERIOR DO TRABALHO. Disponível em: < http://www.tst.gov.br/> . Acesso em: 15 de junho, 2009.

VIANA, Márcio Túlio. Poder diretivo e sindicato: entre a opressão e a resistência. Os novos horizontes do direito do trabalho: homenagem ao Ministro José Luciano de Castilho Pereira. São Paulo: Ltr, 2005, p. 384-411.

VIANA, Márcio Túlio. O sindicato e a proteção ao emprego. Direito coletivo do trabalho em uma sociedade pós-industrial. São Paulo: Ltr, 2003, p. 343-357.

VIANNA, Luiz Werneck. Liberalismo e sindicato no Brasil. $4^{\circ}$ ed.,Belo Horizonte: Ed. UFMG, 1999. 
